\title{
Can Common Business Practices Ever Be Anticompetitive? Redefining Monopolization
}

\author{
Konstantinos Stylianou*
}

For most of its modern history, antitrust law distinguished between normal competition and monopolization by looking for merit, legitimate business justifications, or efficiencies in the challenged business conduct. These proxies were seen as appropriate because they served antitrust law's welfare objectives well. However, the universal adoption of these proxies has overshadowed significant shortcomings, chief among them being that firms do not think in terms of legitimate business justifications or efficiencies, but rather in terms of long-term sustainability and appropriation of value. As a result, antitrust law becomes detached from the very subjects it purports to regulate. Against the backdrop of the recent resurgence of enforcement activity, particularly involving tech giants, this article attempts a conceptualization of monopolization that does not revolve around merit in any form or function. Instead it introduces the proxy of commonness of business practices to determine their legality. This helps highlight the importance of considering "how things are done" in the relevant market, and helps reground antitrust law in business realities, which can enhance the heuristic mechanism of distinguishing between normal and anticompetitive practices. To prove this point the article develops an error test framework, through which it compares current tests with the proposed test in terms of their error

\footnotetext{
*Associate Professor and Deputy Director, Centre for Business Law and Practice, University of Leeds School of Law. Professor Stylianou holds an S.J.D. from the University of Pennsylvania, an LL.M. from Harvard University, and an LL.M. and LL.B. from Aristotle University. This article has benefited greatly from discussions with numerous people, to which I am indebted. I wish to particularly acknowledge help by Pinar Akman, Oles Andriychuk, Sebastian Dengler, Agnieszka Janczuk, Thomaz Pereira, Carlos Ragazzo, Vatsalya Srivastava, Peter Whelan, and the participants in the Yale ISP Ideas Lunch seminar series, the Tilburg TILEC Works in Progress workshop series, and the FGV Works in Progress workshop series.
} 
footprint and concludes that the integration of the commonness parameter delivers better results. Ultimately, the inquiry undertaken herein is not only about constructing a conception of normal competition different from the only standard we currently have, that is, variants of merit, but also about shifting the conversation from how to fine-tune existing standards to how to capture a more complete conception of competition.

\section{INTRODUCTION}

Antitrust law has always struggled to distinguish between normal and unilateral anticompetitive conduct, known as monopolization in the United States and abuse of dominance in the European Union. Done properly, the task would separate practices that tend to increase economic welfare and are labeled normal competition from those that tend to reduce it and are referred to as anticompetitive, monopolistic, or abusive practices. ${ }^{1}$ The task is difficult because the means of illicit conduct and the means of legitimate competition are myriad, and virtually every anticompetitive act has a measure of procompetitive benefits. This exposes the inquiry to heightened subjectivity and potential open-ended interpretation. ${ }^{2}$

There is certainly no shortage of tests to distinguish between normal and monopolistic conduct. Many of them are unhelpful because they are circular. To define, for example, monopolization or abuse of dominance as conduct that "unfairly tends to destroy competition," "[is] directed at smothering competition," "substantially fetter[s] competition," "recourse to methods different from those which condition normal competition" 6 adds little to the inquiry because these formulations contain

\footnotetext{
${ }^{1}$ Lawrence Sullivan et al., The Law of Antitrust: An Integrated Handbook 10-11 (2016); Giorgio Monti, EC Competition Law 22 (2007).

${ }^{2}$ Cf. United States v. Microsoft Corp., 253 F.3d 34, 58 (D.C. Cir. 2001).

${ }^{3}$ Spectrum Sports, Inc. v. McQuillan, 506 U.S. 447, 458 (1993).

${ }^{4}$ Berkey Photo, Inc. v. Eastman Kodak Co., 603 F.2d 263, 275 (2d Cir. 1979).

${ }^{5}$ Case 6/72, Euroemballage Corp. v. Comm'n, 1973 E.C.R. 215, 245 ๆ 26.

${ }^{6}$ Case 85/76, Hoffmann-La Roche \& Co. AG v. Comm’n, 1979 E.C.R. 465, 541 I 91.
} 
terms similar to those they are supposed to prove and are therefore vacuous. ${ }^{7}$

However, the majority of tests are not vacuous, and an interesting-if overlooked-pattern emerges when one looks at them collectively. Virtually every other non-vacuous test antitrust courts and enforcers have devised relies on a showing of merit, legitimate business justifications, or efficiencies to determine that a challenged practice is normal competition as opposed to monopolization or abuse of dominance. This kind of sanctioned competition manifests itself through various terms, including "business acumen,"8 "valid business reasons," "superior product,"10 "traders' performance,"11 "merit,"12 and "procompetitive justification [and] efficiency," 13 and is also prevalent within scholarly discourse. ${ }^{14}$ In other words, vacuous tests aside, we have no other understanding of legitimate competition outside of what can collectively be called competition on the merits.

There is no doubt that competition on the merits, in any of its above variants, is a good standard, as it contributes to increased economic efficiency and welfare-both signs of healthy markets. ${ }^{15}$ Its universal acceptance may even imply that courts, enforcers, and scholars consider it the best available standard. But we will never know how well competition on the merits fares against other possible conceptions of legitimate competition, unless we devise a standard that does not revolve around merit in any form or function. This article is an exploration in that direction. It

\footnotetext{
${ }^{7}$ Einer Elhauge, Defining Better Monopolization Standards, $56 \quad$ Stan. $\quad$ L. Rev. 253, 261-68 (2003).

${ }^{8}$ United States v. Grinnell Corp., 384 U.S. 563, 570-71 (1966).

${ }^{9}$ Eastman Kodak Co. v. Image Tech. Servs., Inc., 504 U.S. 451, 483 (1992).

${ }^{10}$ Aspen Skiing Co. v. Aspen Highlands Skiing Corp., 472 U.S. 585, 596 (1985).

${ }^{11}$ Case C-322/81, Michelin v. Comm'n, 1983 E.C.R. 3467, 3514 ๆ 70.

${ }^{12}$ Case T-228/97, Irish Sugar PLC v. Comm’n, 1999 E.C.R. II-2975, 3021 ฯ 111 (citing Case C-62/86, AKZO v. Comm'n, 1991 E.C.R. I-3359, at ๆ 69).

${ }^{13}$ United States v. Microsoft Corp., 253 F.3d 34, 59 (D.C. Cir. 2001).

${ }^{14}$ See infra notes 58-67 and accompanying text.

${ }^{15}$ Kip W. Viscusi et al., Economics of Regulation and antitrust 79-99 (2005); Joseph Farrell \& Michael L Katz, The Economics of Welfare Standards in Antitrust, 2 Comp. Pol'y Int'L 3 (2006).
} 
moves away from conceptions of merit to distinguish normal and monopolistic business, and instead, it introduces the proxy of commonness of business practices to determine their legality under antitrust law. The commonness test proposition is controversial and not without its problems; however, it is also a rare (or even the only) alternative to competition on the merits, and it can help courts and authorities capture a more complete understanding of competition instead of fine-tuning existing concepts.

The impetus behind the departure from competition on the merits is the observation that the kind of competition that revolves around business justifications and efficiencies is often misaligned with business logic. This, in turn disconnects antitrust analysis from the very entities it purports to regulate. Current tests overlook the fact that firms do not think in terms of legitimate justifications and efficiencies, nor do they prioritize consumer welfare. ${ }^{16}$ Instead, firms think in terms of long-term sustainability and appropriation of value, and consumers are just one of the constituencies that the modern theory of the firm identifies as relevant. ${ }^{17}$ Antitrust matured within a neoclassical economic model and successfully incorporated industrial economics, the field that studies the structure of the market. Along the way, antitrust forgot to pay heed to strategic management, the field that equally if not more so shapes the conduct and operation of businesses. ${ }^{18}$ This creates a problem since courts and authorities may resist benign activities. ${ }^{19}$ The incorporation of commonness into the heuristic of distinguishing between normal and monopolistic or abusive conduct can help reground antitrust law and practice in modern business practices and help antitrust achieve its welfare objectives.

\footnotetext{
${ }^{16}$ See infra Part II.A.

${ }^{17} I d$.

${ }^{18} \mathrm{See} 12$ Strat. Mgmt J. 1-155 (1991) (devoting an entire special issue of this journal to the differences between these models); see also infra Part II.A.

${ }^{19}$ On that point, parts of various cases are discussed infra Part II.A, including United States v. Microsoft Corp., 253 F.3d 34 (D.C. Cir. 2001); Case 77/77, BP v. Comm'n, 1978 E.C.R. 1514; Case 27/76, United Brands Co. v. Comm'n, 1978 E.C.R. 209; Commission Decision 2017 O.J. (C 4444) (involving Case AT.39740 Google Search (Shopping)) [hereinafter Google Search], https://ec.europa.eu/competition/antitrust/cases/dec_docs/39740/39740_ 14996_3.pdf; Commission Decision 2019 O.J. (C 402) 19-22 (involving Case AT.40099 Google Android [hereinafter Google Android].
} 
Specifically, the commonness test suggests that a business practice is normal competition-and therefore not monopolistic - if it is common in the market in which it occurs and not designed to harm competition (the operative word here being designed). This test dispenses with the need to prove legitimate business justifications or efficiencies. What commonness indicates is that the practice is well adapted to the needs and features of the relevant market since multiple firms rationally and independently ${ }^{20}$ think that the practice ensures their survival. As basic as it sounds to consider how things are done in the market, case law to this effect has been scarce, and a gap in legal analysis has yet to be filled.

This proposed approach is admittedly controversial on several grounds. Most obviously, it is tempting to reject the test on the basis that it condones potentially anticompetitive practices simply because they are common. Moreover, the proposed test seems to fall victim to the is-ought fallacy, that is, simply because a state of affairs exists does not mean it should. ${ }^{21}$ Also, whatever the value of commonness, it is not obvious that it should be allowed to take precedence over merit. These and other criticisms are recognized and will be addressed. The commonness test is not infallible, but neither are the tests that rely on business justifications and efficiencies; ultimately the question is which one yields better relative results. To that end, the article develops an error cost framework to juxtapose the error cost of the commonness test in relation to competition on the merits tests. While error cost frameworks are not a novelty in antitrust law analysis, they have remained underused and underdeveloped. ${ }^{22}$ To enhance rigor, an effort is made here to collect and systematize the factors that should be considered to calculate the error cost, including not only the frequency of errors, but also their social impact, persistence, and potential mitigating mechanisms.

Further, while the proposed test gives precedence to the commonness proxy over variants of merit, it integrates well with existing tests, because

\footnotetext{
${ }^{20}$ Since the concept of normal competition is used in situations involving monopolization/ unilateral practices, the scope of the test under that framework is limited.

${ }^{21}$ See John R. Searle, How to Derive “Ought” from "Is," 73 Phil. Rev. 43, 43-58 (1964).

${ }^{22}$ See David S. Evans \& A. Jorge Padilla, Designing Antitrust Rules for Assessing Unilateral Practices: A Neo-Chicago Approach, 72 U. Chi. L. Rev. 73 (2005); Steven C. Salop, Exclusionary Conduct, Effect on Consumers, and the Flawed Profit-Sacrifice Standard, 73 Antitrust L.J. 311 (2006). Additional frameworks are discussed infra Part III.A.
} 
if a practice fails either of the two conditions of the commonness test, examiners may revert to an existing merit test of their choice. Moreover, since commonness is a matter of degree, there is no cut-off point after which the commonness test takes over. Rather, the more common a practice, the less important business justifications and efficiencies become and vice versa. This sliding scale ensures that the commonness parameter takes priority only when its findings are robust.

This article aims to construct a new conception of normal competition that differs from the current merit standard, and in doing so it highlights the importance of factoring in business models and the modus operandi of an industry. It is important to recognize that like other tests, the proposed test does not have an absolute claim to the truth and it accepts that different antitrust law offenses may require the application of different tests. ${ }^{23}$

The article proceeds as follows. Part I documents the dominance of legitimate business justifications and efficiencies in modern antitrust analysis. This will highlight the degree of antitrust law's exposure to any problems associated with these proxies. Part II offers a systematic discussion regarding why exclusive reliance on business justifications and efficiencies is problematic and the need for novel proxies. Part III fills that gap by introducing the commonness test as a possible solution to the identified problem. This part also introduces an error framework to show that incorporating commonness potentially enhances the ability to distinguish between normal and monopolistic conduct.

\section{The Precarious Universality of Business Justifications and Efficiencies as Normal Competition}

For all its significance, what the law understands as normal competition has been and remains elusive. The concept is central to determine the legality or illegality of unilateral competitive conduct of firms with market power. ${ }^{24}$ This is because market power by itself is not an offense-

\footnotetext{
${ }^{23}$ See, e.g., Mark S. Popofsky, Defining Exclusionary Conduct: Section 2, The Rule of Reason, and the Unifying Principle Underlying Antitrust Rules, 73 Antitrust L.J. 435, 437 (2006).

${ }^{24}$ OECD, Competition on the Merits, Report DAF/COMP(2005)27, 17-18 (2005); ALIsON Jones \& Brenda Sufrin, EU Competition Law 378-81 (2014).
} 
rather it is the use of market power toward monopolization of the market (in U.S. terminology) or abuse (in EU terminology) that antitrust law seeks to limit. ${ }^{25}$ Conduct that is deemed normal competition is safe from antitrust liability, even if it is exercised by firms with market power. ${ }^{26}$

One would expect that for a concept that determines the very essence of monopolization, greater certainty would have been achieved by now, at least in major and established antitrust jurisdictions like the United States or the European Union. Yet, the record on how to distinguish normal competition from monopolization is underwhelming. Existing tests either lack definitional clarity and are vacuous, for they define normal competition in a circular manner ${ }^{27}$ or are too narrow since they mandate a specific form of normal competition-competition on the merits—which necessitates provable legitimate business justifications or efficiencies.

The problem with vacuous tests is self-evident, namely, that they do not provide any real guidance. To say that normal competition consists in practices that do not "unfairly tend to destroy competition," 28 "are not directed at smothering competition," ${ }^{29}$ do not "substantially fetter competition," 30 or do not "hinder the maintenance of the degree of competition still existing in the market or the growth of that competition" 31 is tautological and adds little clarity to the inquiry of what is normal.

\footnotetext{
${ }^{25}$ Pinar Akman, The Concept of Abuse in EU Competition Law: Law and Economic Approaches 96, 300-01 (2015); Herbert Hovenkamp, Federal Antitrust Policy: The Law of Competition and Its Practice 295-301 (2011); Lawrence Sullivan et al., The Law of Antitrust: An Integrated Handbook 111-18 (2016). It is important to note that this article does not discuss contracts, collusion, or conspiracy.

${ }^{26}$ The EU competition law concept of special responsibility is clearly in tension with this statement. While the concept is acknowledged, it is intentionally not accounted for here for two reasons: First, because special responsibility is nebulous and practically impossible to properly integrate in any other tool or concept of antitrust law, especially a new and experimental one. Second, because the argument advanced here is jurisdiction-agnostic and thus it is not necessary to limit it with regional controversies.

${ }^{27}$ Elhauge, supra note 7, at 261-68.

${ }^{28}$ Spectrum Sports, Inc. v. McQuillan, 506 U.S. 447, 458 (1993).

${ }^{29}$ Berkey Photo, Inc. v. Eastman Kodak Co., 603 F.2d 263, 275 (2d Cir. 1979).

${ }^{30}$ Case 6/72, Euroemballage Corp. v. Comm'n, 1973 E.C.R. 215 ๆ 26.

${ }^{31}$ Case 85/76, Hoffmann-La Roche \& Co. AG v. Comm'n, 1979 E.C.R. 465, 541 ฯ 91.
} 
Unhelpful as vacuous tests are, they are at least innocuous in the sense that they do not meaningfully influence the analysis of monopolization, since they lack substance. The same cannot be said for all other remaining tests, which make normal competition contingent on the showing of "merit," "business acumen," "business justifications," "superior product," or "efficiency," among other similar terms. These proxies can be observed and measured to some degree, and therefore they establish specific benchmarks of what constitutes normal competition and monopolization. The above benchmarks all converge toward what is collectively called competition on the merits, which requires a showing of legitimate business justifications or efficiencies. ${ }^{32}$ If this is true, and it is argued below that it is, then there is an inextricable link between normal competition and competition on the merits, such that the establishment of the monopolization offense always depends on a showing of lack of legitimate business justifications or efficiencies. This observation is problematic for standard antitrust law analysis because the conventional wisdom of antitrust law does not seem to recognize that normal competition is necessarily the same thing as competition on the merits. A few more details are therefore due here, before moving on to proving that all available nonvacuous tests on how to distinguish between normal competition and monopolization require a showing of legitimate business justifications or efficiencies.

To equate normal competition with competition on the merits is to say that for firms to engage in normal competition they must restrict themselves only to the kind of competition on the merits accepted by the law. This, paradoxically, turns the function of antitrust law on its head, from a framework that enables free markets by prohibiting only specific anticompetitive conduct ${ }^{33}$ to a framework that mandates a specific type of competitive conduct - that which exhibits legitimate business justifications or efficiencies. This observation runs contrary to the commonly shared intuition about how antitrust law works, which is that all conduct is permissible normal competition unless it is shown that certain conduct produces anticompetitive effects (setting aside the few exceptions of per se illegality), at which point the challenged firm must defend its conduct by proving that its conduct can be pardoned on the grounds of business

\footnotetext{
${ }^{32}$ For an overview, see generally OECD, supra note 24.

${ }^{33}$ Eleanor M. Fox, What Is Harm to Competition? Exclusionary Practices and Anticompetitive Effect, 70 Antitrust L.J. 371, 371 (2002).
} 
justifications or efficiencies. ${ }^{34}$ In other words, the common intuition seems to be that business justifications or efficiencies are a defense to an established case of monopolistic behavior-not that business justifications or efficiencies are an integral element of normal competition.

The prevailing intuition is misplaced. If the main goal of antitrust law, as conventionally accepted, is to protect against consumer harm, ${ }^{35}$ this harm must logically and necessarily be construed as net harm, namely, residual harm that is borne by consumers after discounting it by the benefits, such as business justifications or efficiencies, that the allegedly monopolistic conduct created. Therefore, to establish a case of monopolization one would have to prove net harm. ${ }^{36}$ Otherwise, it would be enough to simply point to any measure of harm, even if it is manifestly offset by benefits, a trivial endeavor since virtually every competitive action results in some sort of harm for at least some consumers. ${ }^{37}$ This position cannot be saved by saying, as per above, that benefits resulting from conduct are indeed taken into account, and it is just that the burden of proof lies exclusively with the defendant firm. The allocation of burden of proof is a procedural rule that serves purposes of practicality, efficiency, and broader policy considerations; it is not a substantive rule that affects what needs to be proven. ${ }^{38}$ Rebuttable presumptions employed in antitrust law have a similar function-they automate decision-making by incorporating prior knowledge on the net harm of certain practices as it has emerged through prior case law and literature. ${ }^{39}$ Splitting the burden of proof and the

\footnotetext{
${ }^{34}$ The Microsoft and Kodak cases in the United States—discussed below-and the EU Commission's Guidance on Enforcement Priorities in Applying Article 82 of the Treaty on the Functioning of the European Union articulate this balance. See Commission Communication of Feb. 24, 2009, Guidance on the Commission's Enforcement Priorities in Applying Article 82 of the EC Treaty to Abusive Exclusionary Conduct by Dominant Undertakings, 2009 O.J. C45/7.

${ }^{35}$ See Sullivan ET AL., supra note 1.

${ }^{36}$ Акмал, supra note 25 , at 280-83.

${ }^{37}$ See, e.g., Simon Cowan \& Xiangkang Yin, Competition Can Harm Consumers, 47 Austl. ECON. PAPERS 264-71 (2008).

${ }^{38}$ Andrew Gavil, Burden of Proof in U.S. Antitrust Law, 1 Issues Comp. L. \& Pol’y 125, 126-28 (2008).

${ }^{39}$ Steven C. Salop, An Enquiry Meet for the Case: Decision Theory, Presumptions, and Evidentiary Burdens in Formulating Antitrust Legal Standards (Nov. 6, 2017) (unpublished manuscript), https://scholarship.law.georgetown.edu/cgi/viewcontent.cgi?article $=3025 \&$ context $=$ facpub.
} 
creation of presumptions allow courts and authorities to establish a prima facie case that involves anticompetitive conduct, yet is open to rebuttal if the challenged firm produces evidence that had not been considered or assessed properly in establishing the prima facie case. This is allowed to economize on the prosecutorial process and to assist with legal certainty. However, the rules regarding burden of proof and presumption do not relieve courts and authorities of their duty to consider legitimate business justifications and efficiencies as part of the initial assessment of monopolization; they simply lower the threshold of what needs to be proven to establish the prima facie case. ${ }^{40}$ The unreasonable alternative would be tantamount to asking the defendant firm to disprove an insufficiently established allegation of monopolization. ${ }^{41}$

On close inspection neither theory nor practice define normal competition and monopolization separately and independently from justifications, efficiencies, and harm. These concepts are all intertwined in the firm's conduct such that normal competition today cannot conceptually exist without a showing of business justifications or efficiencies. Conduct that is linked to competitive harm, and that fails to demonstrate any justifications on the merits-even if it shows neutral nonmerit justificationsis unlikely to be considered normal competition. ${ }^{42}$ The consensus described below characterizes both the U.S. and the EU jurisdictions and is shared among courts and scholars alike.

Along those lines, perhaps the most famous test to distinguish between normal competition and monopolization came from the U.S. Supreme Court in United States v. Grinnell Corp., where the Court defined monopolization as consisting in "the willful acquisition or maintenance of [monopoly power] as distinguished from growth or development as a consequence of a superior product, business acumen, or historic accident." ${ }^{43}$ The Court did not provide much detail as to what this requirement entailed, perhaps because it concluded that the requirement was clearly met insofar as the case concerned division of markets and price

\footnotetext{
${ }^{40}$ Gavil, supra note 38, at 129-31.

${ }^{41}$ AкмаN, supra note 25 , at 280-81.

${ }^{42}$ See, e.g., United States v. Microsoft Corp., 253 F.3d 34, 72 (D.C. Cir. 2001); Eirik Østerud, Identifying Exclusionary Abuses by Dominant Undertakings under EU Competition Law: The Spectrum of Tests 42 (2010).
}

${ }^{43} 384$ U.S. $563,570-71$ (1966). 
discrimination. It is evident, however, that the Court linked normal competition to efficiencies and merit since it held that for conduct to be considered normal competition, it needs to be justified on the basis of growth or development attributable to superior performance. Aspen Skiing Co. v. Aspen Highlands Skiing Corp. ${ }^{44}$ reflects similar thinking. That case concerned a refusal to deal by a dominant firm for allegedly no reason other than to eliminate a competitor. The district court's instruction to the jury on the question of monopolization-which was not challenged on appeal-concerned the distinction "between practices which tend to exclude or restrict competition on the one hand and the success of a business which reflects only a superior product, a well-run business, or luck, on the other." 45

Aspen Skiing, which affirmed the decision of the lower courts that defendant had committed an antitrust violation, further added legitimate business justifications as one of the main determinants of normal competition. In its jury instructions the district court specified that "if there were legitimate business reasons for the refusal, then the defendant, even if he is found to possess monopoly power in a relevant market, has not violated the law... [O]btaining or maintaining monopoly power cannot represent monopolization if the power was gained and maintained by conduct that was honestly industrial." ${ }^{46}$ In Olympia Equipment Leasing Co. v. Western Union Telegraph Co., a similar case concerning duties between competitors, the Seventh Circuit ruled that "conjoined with other evidence, lack of business justification may indicate probable anticompetitive effect." 47

The landmark decisions by the Court of Justice of the EU (CJEU) in AKZO v. Commission ${ }^{48}$ and Irish Sugar plc v. Commission ${ }^{49}$ also echo the emphasis on meritorious competition by noting that "Article 86 of the Treaty [now 102] prohibits a dominant undertaking from eliminating a competitor and thereby reinforcing its position by having recourse to

\footnotetext{
${ }^{44} 472$ U.S. 585 (1985).

${ }^{45} I d$. at 596 .

${ }^{46} I d$. at 597 .

${ }^{47} 797$ F.2d 370, 378 (7th Cir. 1986).

${ }^{48} 1991$ E.C.R. I-3359.

${ }^{49} 1999$ E.C.R. II-2975.
} 
means other than those within the scope of competition on the merits." 50 Similarly, in British Airways v. Commission, the Court of First Instance stated that "the protection of the competitive position of an undertaking which ... occupies a dominant position must, at the very least, in order to be lawful, be based on criteria of economic efficiency." ${ }^{11}$

In United States v. Microsoft Corp. the D.C. Circuit held that firm conduct that has been found to have anticompetitive effects can be excused if there are "procompetitive justification[s]," which the court defined as "a nonpretextual claim that [the monopolist's] conduct is indeed a form of competition on the merits because it involves, for example, greater efficiency or enhanced consumer appeal." 52 And in Eastman Kodak Co. v. Image Technical Services, Inc., the U.S. Supreme Court held that once evidence of exclusionary action has been produced "[l]iability turns, then, on whether 'valid business reasons' can explain [the firm's] actions." ${ }^{\text {"3 } 3}$ These two cases seem to reserve a separate step for the assessment of efficiencies and justifications, and in that sense merit is not inextricably enshrined in the inquiry of the firm's conduct and whether it constitutes normal competition. ${ }^{54}$ The Microsoft court, in an effort to systematize prior case law, built a three-step approach whereby plaintiffs must show that (1) a monopolist's act has an anticompetitive effect, ${ }^{55}$ (2) the anticompetitive injury is "of "the type that the [antitrust] statute was intended to forestall," 56 and then (3) "if a plaintiff successfully establishes a prima facie case under [the antitrust statute] by demonstrating anticompetitive effect, then the monopolist may proffer a 'procompetitive justification' for its conduct." 57 This distinction makes it look like the test of what constitutes normal competitive conduct is self-contained in the second strand, while efficiencies and justifications are exclusively a defense if the second strand is proven.

\footnotetext{
${ }^{50} I d$. at 3021 ฯ 111 .

${ }^{51}$ Case T-219/99, 2003 E.C.R. II-5925, at 『 280.

${ }^{52}$ United States v. Microsoft Corp., 253 F.3d 34, 59 (D.C. Cir. 2001).

${ }^{53} 504$ U.S. 451, 483 (1992).

${ }^{54}$ Gavil, supra note 38 , at 133 .

${ }^{55}$ Microsoft, 253 F.3d at 58-59.

${ }^{56} I d$. (citing Brunswick Corp. v. Pueblo Bowl-O-Mat, Inc., 429 U.S. 477, 487-88 (1977) and quoting Wyandotte Transp. Co. v. United States, 389 U.S. 191, 202 (1967)).

${ }^{57} I d$.
} 
This distinction may have made sense if the court had not used vague language to determine the content of the normal competitive conduct requirement in the second strand. With the conduct requirement out, the question of what is normal and what is monopolizing conduct becomes a nebulous mix of a conduct's effects and justifications, and the only function these distinctions serve is to allocate the burden of proof, not to determine what needs to be proven.

The tendency to condition normal competition on the basis of business justifications and efficiencies is accepted by legal scholars as well. ${ }^{58}$ Notably, none of the available scholarly tests treats justifications and efficiencies simply as a defense to an otherwise defined concept of normal competition. This validates the argument that merit is an integral and indispensable element of normal competition.

One of the popular versions of the merit test is the equally efficient competitor test, which asks whether the conduct under scrutiny is likely to exclude rivals that are equally or more efficient than the dominant firm, and if the answer is yes then the conduct is unlawful. ${ }^{59}$ Use of the test has been popular in pricing abuse cases, ${ }^{60}$ although Judge Richard Posner finds it appropriate as a generalized test. ${ }^{61}$ An alternative test, the consumer welfare test, determines the merits of competitive conduct regardless of how it compares with rivals' efficiency. It instead balances the efficiency gains from the business conduct under question, and the potential harm to competition produced by it, and it prohibits the conduct if the harm outweighs the gains. ${ }^{62}$ The consumer welfare test does

\footnotetext{
${ }^{58}$ See generally Albert Foer, On the Inefficiencies of Efficiency as the Single-Minded Goal of Antitrust, 60 Antitrust Bull. 103 (2015).

${ }^{59}$ OECD, supra note 24, at 29.

${ }^{60}$ See, e.g., Case 52/09 Konkurrensverket v. TeliaSonera Sverige AB, 2011 E.C.R. I-564. See also Martin Mandorff \& Johan Sahl, The Role of the 'Equally Efficient Competitor' in the Assessment of Abuse of Dominance 3-15 (Konkurrensverket Working Paper Series in Law and Economics 2013), http://www.konkurrensverket.se/globalassets/english/publications-anddecisions/the-role-of-the-equally-efficient-competitor-in-the-assessment-of-abuse-ofdominance.pdf.

${ }^{61}$ Richard A. Posner, Antitrust Law 194 (2001).

${ }^{62}$ OECD, supra note 24, at 31. See also Steven C. Salop, Exclusionary Conduct, Effect on Consumers, and the Flawed Profit-Sacrifice Standard, 73 Antitrust L.J. 311 (2006); Steven C. Salop \& R. Craig Romaine, Preserving Monopoly: Economic Analysis, Legal Standards, and Microsoft, 7 George Mason L. Rev. 617 (1999).
} 
not really escape the comparison problem, because it still needs to compare welfare and efficiency gains and losses, and this has proven difficult. ${ }^{63}$ Professor Elhauge removes the balancing part altogether, and focuses instead on the question of whether the conduct under scrutiny furthers the firm's dominant position by improving the firm's efficiency regardless of whether it also negatively affects rival efficiency, or if it furthers the firm's dominant position by impairing rival efficiency whether or not it enhances the monopolist's efficiency. ${ }^{64}$ In the former case, the conduct is acceptable despite potential harm to competitors, whereas in the latter case, the conduct is unacceptable despite incidental gains in own efficiencies.

Other tests do not reserve a central role for efficiencies, yet, they still incorporate them as a relevant factor. For instance, Professor Akman's definition of abuse of dominance is conduct that is exploitative, exclusionary, and devoid of offsetting efficiencies that require balancing. ${ }^{65}$ Finally, the no economic sense test holds that conduct should be unlawful if it makes no economic sense absent its tendency to eliminate or lessen competition. ${ }^{66}$ While economic sense does not necessarily imply efficiencies or business justifications, in practice it has been interpreted that way. ${ }^{67}$

The merits of promoting business justifications and efficiencies are evident, and in that sense, one should celebrate their inclusion in normal competition tests. But despite the benefits, one should question whether it is good policy to rely on them as universal conditions. The following part explains why the exclusive reliance on business justifications and efficiencies generates underappreciated drawbacks.

\footnotetext{
${ }^{63}$ OECD, supra note 24, at 31; Elhauge, supra note 7, at 315 .

${ }^{64}$ Elhauge, supra note 7 , at 315 .

${ }^{65}$ Aкman, supra note 25, at 316-19.

${ }^{66}$ Gregory J. Werden, The No Economic Sense Test for Exclusionary Conduct, 31 J. Conp. L. 293 (2006). See also OECD, supra note 24, at 27.

${ }^{67}$ See, e.g., United States v. Microsoft Corp., 253 F.3d 34 (D.C. Cir. 2001).
} 


\section{Business Justifications, Efficiencies, And their Discontents}

Competition on the merits as developed through the numerous judicial and scholarly tests discussed above is linked to heightened consumer welfare and dynamic efficiency, both of which are significant metrics of a well-performing economy ${ }^{68}$ However, as competition on the merits cemented itself as practically synonymous with normal competition, it left little to no margin for competitive conduct that does not demonstrate provable procompetitive business justifications or efficiencies. ${ }^{69}$ Banning such conduct may still deprive society of practices that are neutral or even procompetitive, just not in a way that competition on the merits would recognize. Despite the universal acceptance, this part challenges the complete dominance of business justifications and efficiencies as proxies to normal competition.

\section{A. Firm Activity Beyond Business Justifications and Efficiencies}

The first problem with making valid business justifications and efficiencies a universal requirement to the finding of normal competition is one of misalignment. Current tests suggest that competition authorities and courts expect firms to compete on the grounds of superiority, progress, innovation, efficiency, cost reduction, or more generally to have procompetitive justifications for their market practices. From a policy point of view, this seems appropriate as it is associated with the benefits of welfare and dynamic efficiency maximization. It is worth noting, however, that at the same time and perhaps inadvertently, this requirement, because it is universal, restricts firms to this specific type of competition on the merits. The problem with that is that firms think about competition and their market strategy differently from antitrust law, not in terms of efficiencies or "legitimate" justifications, but in terms of long-term sustainability, and while the latter can be served by the former, that is not

\footnotetext{
${ }^{68}$ See supra note 15 and accompanying text.

${ }^{69}$ For reasons different than those identified herein, namely, the marginalization of competition as process rather than as outcome, Andriychuk also laments the obsession of antitrust law with achieving efficiencies and welfare gains. See Oles Andriychuk, Can We Protect Competition Without Protecting Consumers?, 6 Comp. L. Rev. 77-87 (2010).
} 
always the case. ${ }^{70}$ As a result, the insistence on competition on the merits creates a misalignment between the expectations of antitrust law and the nature and purpose of the firm, undermining the effectiveness and legitimacy of antitrust law.

As was discussed in Part I, courts and regulators in antitrust matters expect firms to win by outperforming competitors through practices that promote efficiency or offer other procompetitive justifications. Since there is no exact definition of how efficiencies and procompetitive justifications are to be construed, contextual details become useful. For example, legitimate efficiencies and justifications are those that "increase social welfare,"71 "make consumers [better] off in the long run,"72 or "preserve proper economic incentives."73 They also cannot simply be neutral or serving the introducing firm. Instead, they must be positively procompetitive, and their effects should spill over to consumers or the market. ${ }^{74}$ In other words, while the economic incentives of firms are taken into account, they are only valid as long as they also serve the broader public in a positive way.

Firms have different motivations. While the broader public welfare is an important consideration, it is only part of the equation. For corporate financiers the traditional goal of the firm has been to serve its owners, ${ }^{75}$ and while newer approaches look more widely to include not just

\footnotetext{
${ }^{70}$ For a succinct summary, see Norman W. Hawker, The Public Policy of Antitrust and Strategy: An Overview, 21 J. Pub. Pol’y \& Mктg. 257 (2002).

${ }^{71}$ Microsoft, 253 F.3d at 58.

${ }^{72}$ Olympia Equip. Leasing Co. v. W. Union Tel. Co., 797 F.2d 370, 379 (7th Cir. 1986).

${ }^{73}$ Berkey Photo, Inc. v. Eastman Kodak Co., 603 F.2d 263, 276 (2d Cir. 1979).

${ }^{74}$ See, e.g., Microsoft, 253 F.3d at 72. Similarly, in the European Union, efficiencies should consist of the enhancement or the introduction of a new product or service, or in lowering the price. They also need to be objective, cannot be purely internal but rather must trickle down to consumers, and should not eliminate competition. See Commission, Guidelines on the Application of Article 81(3) of the Treaty 2004 O.J. (C101/08), 97, 97-118 [hereinafter Commission Guidelines]. These guidelines may refer to agreements, but they have also been deemed to apply to abuse of dominance. See, e.g., Case C-209/10, Post Danmark A/S v. Konkurrencerådet, 2012 E.C.R. 172, ๆศ 40-41.

${ }^{75}$ Stephen M. Bainbridge, In Defense of the Shareholder Wealth Maximization Norm: A Reply to Professor Green, 50 Wash. \& Lee L. Rev. 1423, 1423 (1993); Bernard Black \& Reinier Kraakman, A Self-Enforcing Model of Corporate Law, 109 Harv. L. Rev. 1911 (1996). For the business strategy perspective, see Michael R. Baye \& Jeffrey T. Prince, Managerial EconomiCS AND Business STRATegy (2014).
} 
shareholders but a broader community of stakeholders, including society at large, a balancing of interests is required, and consumers or society are not guaranteed to be the priority consideration. ${ }^{76}$ Behavioral theories of the firm further emphasize firms' multitude of goals and interests, which are expressed through the tussle among the constituent actors of the coalition that forms the firm. ${ }^{77}$ Modern firm theory clarifies that when serving these varied interests firms do not focus on short-term profit maximization and the pricing mechanism in general. ${ }^{78}$ Instead, they take a long-run approach that emphasizes long-term sustainability leveraging the firm's unique assets. ${ }^{79}$

Importantly, as the theory of the firm moved away from singular short-term profit maximization and toward long-run strategic management goals, it became apparent that a necessary element of sustainable strategic business models was necessary to allow the firm to capture the value of its choices, rather than let it dissipate into the value chain. ${ }^{80}$ Appropriability of value, rather than just value creation, is what sustainable business strategies and models should deliver, because otherwise firms cannot capture returns on their investments. ${ }^{81}$ However, business strategies and models that increase appropriability of value for the firm can be in tension with consumers or other firms' interests, since value that is not captured by the firm is value that will be captured by consumers or other firms. ${ }^{82}$

\footnotetext{
${ }^{76}$ R. Edward Freeman, Strategic Management: A Stakeholder Approach (2010).

${ }^{77}$ Richard M. Cyert \& James G. March, A Behavioral Theory of the Firm (1963).

${ }^{78}$ Eugene F. Fama \& Merton H. Miller, The Theory of Finance (1972).

${ }^{79}$ Paul F. Anderson, Marketing, Strategic Planning and the Theory of the Firm, 46 J. MкTG. 15, 15 (1982); Kathleen R. Conner \& C.K. Prahalad, A Resource-Based Theory of the Firm: Knowledge Versus Opportunism, 7 ORG. ScI. 477 (1996); Robert M. Grant, Toward A KnowledgeBased Theory of the Firm, 17 Strategic Mgmt. J. 109, 109 (1996); Richard Nelson \& Sidney Winter, Toward an Evolutionary Theory of Economic Capabilities, 63 Aм. Econ. Rev. 440, 440 (1973).

${ }^{80}$ David J. Teece, Profiting from Technological Innovation: Implications for Integration, Collaboration, Licensing and Public Policy, 15 Res. PoL'y 285, 285 (1986).

${ }^{81}$ David J. Teece, Business Models, Business Strategy and Innovation, 43 Long Range Planning $172(2010)$.

${ }^{82}$ See Marco Ceccagnoli, Appropriability, Preemption, and Firm Performance, 30 Strategic Mgmt. J. 81 (2008).
} 
Overall, firms do not decide their business strategy on whether every one of their actions will promote progress, enhance efficiency, benefit consumers, and leave room for competition. Instead, what drives corporate strategy is long-term sustainability and appropriability of value. Sometimes this will be achieved through innovations, technological progress, or resource-economizing techniques, thereby aligning firms' actions with the type of competition on the merits that courts and authorities expect. However, other times it may not. For example, in Microsoft, the D.C. Circuit scrutinized the exclusive dealing requirements Microsoft imposed on independent software vendors. For Microsoft, these terms were important as they were meant to "keep developers focused upon Windows." ${ }^{83}$ However, the D.C. Circuit, while recognizing that the agreements were not themselves anticompetitive, called their justification a "competitively neutral goal" (emphasis added) and found an antitrust violation in the absence of a procompetitive justification. ${ }^{84}$ This signaled a divergence between what matters to companies and what courts are willing to consider.

The difference between legal and business thinking is also palpable in the Google Search case. The European Commission (Commission) found Google's conduct abusive because Google "artificially reaped the benefits" of the conduct, favorably positioning its own comparison shopping service over those of its competitors to their likely detriment, as it did not itself "invent comparison shopping." 85 Among Google's arguments was that its conduct was simply a matter of common business sensenamely, that search engines compete in the market "by showing their results, not results from other services [since] users do not expect search services to provide results from other services," and that its conduct was necessary to allow it "to monetize space on its general search results pages." ${ }^{86}$ Google did not design its services to harm competition or force

\footnotetext{
${ }^{83}$ United States v. Microsoft Corp., 253 F.3d 34, 72 (D.C. Cir. 2001).

${ }^{84} I d$.

${ }^{85}$ Google Search, Commission Decision 2017 O.J. (C 4444), ๆ 343.

${ }^{86} I d$. at 9 657. The same argument about commonness and monetization was also made in the Google Android case. Google argued that its tying was similar to that performed by other firms in the market and was essential for it to recoup the cost of maintaining the Android ecosystem. See Geoffrey Manne, The EU's Google Android Antitrust Decision Falls Prey to the Nirvana Fallacy, TRuth on The MARket (July 18, 2018), https://truthonthemarket.com/2018/07/ 18/the-eus-google-android-antitrust-decision-falls-prey-to-the-nirvana-fallacy/.
} 
a choice upon consumers. Rather, the demise of competitors was the result of users relying more on Google's offering, which it introduced as a way of maximizing the utility and value appropriability of its services. Apparently, this was not a valid business justification for the Commission.

There are other examples of practices-primarily from the European Union-that seemed to make complete business sense, were not targeted at smothering competition, and did not eliminate competition but simultaneously did not advance the ideal of competition on the merits and were therefore met with resistance from regualtors and courts. In $B P$ v. Commission, a case that concerned British Petroleum's reduction of oil supply to one of its occasional retailers during a period of extreme oil shortage during the worldwide oil crisis of 1973-74, the Commission found that this tactic was outside the scope of normal competition, particularly because BP had reduced its supplies to the complainant retailer to a much greater extent than it had reduced those made to its regular customers. ${ }^{87}$ The CJEU ultimately reversed the Commission's decision, ${ }^{88}$ but the Commission's decision stands as an example of the divergence between what firms consider a legitimate business strategy (i.e., prioritizing loyal retailers when production does not suffice for all) and what courts and authorities are willing to allow. In United Brands Co. v. Commission the CJEU scrutinized the decision of a producer to cut off supply to a retailer who sided with competitors. ${ }^{89}$ The CJEU opined that it was "necessary to ascertain whether the discontinuance of supplies was justified" $" 90$ but ultimately ruled that this was a disproportionate measure. Without proof of any sinister plan or anticompetitive effect, it is unclear why choosing to disassociate from a hostile retailer-a tactic that admittedly does not subscribe to the competition on the merits modelis not a legitimate business decision. ${ }^{91}$

\footnotetext{
${ }^{87}$ Commission Decision Relating to a Proceeding Under Article 86 of the EEC Treaty (IV/28.841-Abg Oil Companies Operating in the Netherlands), 77/327/EEC, 1977 O.J.L. 117.

${ }^{88}$ Case 77/77, BP v. Comm'n, 1978 E.C.R. 1514.

${ }^{89}$ Case 27/76, 1978 E.C.R. 209.

${ }^{90} I d$. 184.

${ }^{91}$ For a critique, see Per Jebsen \& Robert Stevens, Assumptions, Goals and Dominant Undertakings: The Regulation of Competition Under Article 86 of the European Union, 64 Antitrust L.J. 443 (1996).
} 
This mismatch between legal and business thinking might be explained by the blind spot courts and regulators in antitrust matters have for firms' internal operations. They see firms as black boxes that compete homogeneously against every other firm in the market. But far from being mere competitive automata, firms have internal motives, strategies, capabilities, weaknesses, cultures, and limitations that shape their conduct in the market, ${ }^{92}$ and while they all share a common survival instinct, their ways of staying afloat are diverse and not limited to any preconceived notion, whether efficiency, profit maximization, or something else. ${ }^{93}$ It is indicative that the way business schools generally teach about competition omits almost any reference to antitrust law, and they often fail to link competition to efficiencies or a concept of legitimate business justifications. ${ }^{94}$ As Albert Foer, former president of the American Antitrust Institute, reported on the findings of an investigation conducted by the Institute on the relationship between business schools and antitrust, "[w]hereas Chicago School economists tended to focus on theoretical models based on assumptions about how people act, the business schools tended to focus on empirical understanding of what in fact works in the marketplace-not the marketplace of ideas but the marketplace of commerce." $" 95$

There is, of course, no denying that antitrust law can place limits to how firms can conduct themselves in the marketplace. The fact that a course of action makes business sense does not mean it should be unconditionally allowed, and this is not what is suggested here. However, by mandating competition on the merits, antitrust law does not simply place

\footnotetext{
${ }^{92}$ See, e.g., Jay B. Barney, Organizational Culture: Can It Be a Source of Sustained Competitive Advantage?, 11 Acad. MGmt. Rev. 656-65 (1986). Firms also consider legal strategy consideration as an aspect of business strategy. See Robert C. Bird \& David Orozco, Finding the Right Corporate Legal Strategy, 56 MIT SloAn MGMT. Rev. 81, 81-82 (2014) (discussing how law, in general, can be used to achieve private strategic benefits rather than just compliance or risk management-related goals); Larry A. DiMatteo, Strategic Contracting: Contract Law as a Source of Competitive Advantage, 47 Am. Bus. L.J. 727, 735 (2010) ("[C]ontract is the most flexible, strategic tool that the law offers to the business community.").

${ }^{93} \mathrm{On}$ the variety and diversity of business goals and models, see Scott M. Shafer et al., The Power of Business Models, 48 Bus. Horizons 199 (2005).

${ }^{94}$ Norman W. Hawker, Antitrust Insights from Strategic Management, 47 N.Y.L. ScH. L. Rev. 67 (2003).

${ }^{95}$ Foer, supra note 58. See also Albert A. Foer, The Third Leg of the Antitrust Stool: What the Business Schools Have to Offer to Antitrust, 47 N.Y.L. Sch. L. Rev. 21 (2003).
} 
limits on what companies can do; it rather imposes a specific obligation. This inverts the function of antitrust law from a body of regulations that starts from the free market assumption and carves out exceptions to a body of regulations that directs how firms should operate in the market. While the intentions behind this are benign, the result is that firms are limited to a single form of competition, which undermines the effectiveness and legitimacy of antitrust law.

Indeed, antitrust law, like any other form of regulation, is most effective when it is attuned to but not captured by its regulated base. As Professors Ayres and Braithwaite have influentially argued, "regulation [should] be responsive to industry structure in that different structures will be conducive to different degrees and forms of regulation. Efficacious regulation should speak to the diverse objectives of regulated firms, industry associations, and individuals within them." 96 If antitrust law standards are out of touch with the realities of those that it regulates, compliance becomes less likely in light of companies' capacity for compliance and their motivation for compliance-including economic, social, or normative factors. ${ }^{97}$ This intuitive outcome can be traced back to neoinstitutional theory, which suggests that legal and regulatory norms should be impacted by its regulated subjects and vice versa. ${ }^{98}$

It would be unfair to say that current antitrust standards completely ignore the nature of the firm, but it is also hard to see how they can claim to be workable when they, on the other hand, largely ignore what firms do. In that sense, a test that prioritizes commonness, as opposed to simply making it a relevant parameter, may seem like an extreme solution. While this is a fair point, at least three reasons justify the development of a new test that revolves around commonness. The first is that the commonness test has the potential to deliver better and more realistic results than existing tests. The second justification is that mild proposals may fail to generate the necessary change, similar to the chronic failure of courts and regulators to assign more weight to efficiencies, as analyzed below. More drastic proposals are therefore required to shift the

\footnotetext{
${ }^{96}$ Ian Ayres \& John Braithwaite, Responsive Regulation: Transcending the Deregulation Debate 4 (1995).

${ }^{97}$ Christine Parker \& Vibeke Lehmann Nielsen, Explaining Compliance: Business Responses to Regulation (2011).

${ }^{98}$ W. Richard SCOtT, InStitutions and Organizations (2001).
} 
discussion. The third reason is that, even if the commonness test fails to catch on, it will be the first workable alternative to the prevailing dominance of merit and is therefore a step in the direction of reconceptualizing how antitrust law relates to its subjects.

\section{B. The Prohibitively High Threshold of Business Justifications and Efficiencies}

Assuming that valid business justifications and efficiencies are a good proxy to determine what constitutes normal competition and monopolization, a further difficulty emerges, this time with proving the alleged justifications and efficiencies. If the relevant tests revolve around conditions that are prohibitively hard to meet, then such tests are not correctly calibrated to serve their goals. Indeed, business justifications and efficiencies are notoriously hard to prove, whether as a defense or as part of the very definition of normal competition. It took an entire school of thought-the Chicago School—to even bring legitimate business justifications and efficiencies to the table. ${ }^{99}$ As Professor Hovenkamp said,

Undoubtedly the most lasting legacy of the problems attending the New Deal and the recovery was the increasing attempt by antitrust policy makers after World War II to take efficiency concerns more seriously, and to recognize that bigness and even a certain amount of oligopoly were a fact of life. $^{100}$

It is conventionally thought that prior to the rise of the Chicago School, antitrust policy was dominated by a formalistic approach informed mainly by ordoliberalism (in Europe) and the structure-conduct-performance model (in the United States), where the legality of business conduct was assessed on the basis of predefined market structure conceptions. These included no dominant firms and low market concentration, and any conduct that threatened this vision was deemed anticompetitive. ${ }^{101}$ The Chicago School contested these automatic

\footnotetext{
${ }^{99}$ See Richard Schmalensee, Thoughts on the Chicago Legacy in U.S. Antitrust, in How the ChIcago School Overshot the Mark: The Effect of Conservative Economic Analysis on U.S. Antitrust 11 (Robert Pitofsky ed., 2008).

${ }^{100}$ Herbert Hovenkamp, Federal Antitrust Policy: The Law of Competition and Its PracTICE 75 (2011).

${ }^{101}$ James W. Meehan Jr. \& Robert J. Larner, The Structural School, Its Critics, and Its Progeny: An Assessment, in Economics and Antitrust Policy 182 (James W. Meehan Jr. \& Robert J. Larner eds., 1989); Leonard W. Weiss, The Structure-Conduct-Performance Paradigm and Antitrust, 127 U. Penn. L. Rev. 1104 (1979).
} 
conclusions and insisted that business conduct should be outlawed only if it was shown to have anticompetitive effects. Potential efficiencies and legitimate business justifications were to be included in the assessment of the net effects of business conduct. ${ }^{102}$ The United States was the first jurisdiction to adopt the approach of the Chicago School. The Commission and the CJEU initially resisted this transition, but landmark policy documents and decisions in the early 2000s were seen as a sign of embracing this approach. ${ }^{103}$

The movement was successful because it moved a large number of business practices out of the per se liability category and into the rule of reason category, and proved-at least in theory-the potential procompetitive effects of vertical and even some horizontal restraints. This gave firms a chance to argue that some of their practices, which in the past were considered unsalvageably anticompetitive, could survive antitrust scrutiny if no anticompetitive effects were proven, or if the anticompetitive effects were offset by procompetitive justifications or efficiencies.

That last part, however, proved tricky. Firms discovered that practices that had a measure of anticompetitive effects were next to impossible to save, because courts and authorities never put much credence in legitimate justifications and efficiencies, despite acknowledging them as a relevant parameter. ${ }^{104}$ In a survey of all cases involving abuse of dominance since 2009 (article 102 of the Treaty on the Functioning of the European Union (TFEU)), Friederiszick and Gratz concluded that "[a]lmost every firm that presented a justification in the Article 102 TFEU cases ... failed to convince the EU Commission of the justification's relevance."105 Indeed, in many landmark cases, including United Brands, BP, and Google Search, the objective justifications or efficiencies offered by the defendant

\footnotetext{
${ }^{102}$ Herbert J. Hovenkamp, The Harvard and Chicago Schools and the Dominant Firm, in How the Chicago School Overshot the Mark: The Effect of Conservative Economic Analysis on U.S. ANTITrust 109 (Robert Pitofsky ed., 2008).

${ }^{103}$ See, e.g., Anne C. Witt, The More Economic Approach to EU Antitrust LaW (2016).

${ }^{104}$ See Jean-Francois Bellis \& Tim Kasten, Will Efficiencies Play an Increasingly Important Role in the Assessment of Conduct Under Article 102 TFEU?, 55 Antitrust Bull. 915, 918 (2010) (stating that "[i]n effect, an efficiency-based argument is treated as a request for an exemption, an almost impossible burden to meet").

${ }^{105}$ Hans Friederiszick \& Linda Gratz, Hidden Efficiencies: The Relevance of Business Justifications in Abuse of Dominance Cases, 11 J. Comp. L. \& Econ. 671, 680 (2015).
} 
firms were acknowledged but rejected by the Commission or the CJEU. ${ }^{106}$ Part of the problem is that "the EU Commission's decisions have not included a transparent discussion of justifications"107_even where the Commission addressed the justifications, it did not engage in a detailed discussion. But the bigger challenge is that the standard of proof required to accept such justifications is too high. The Commission requires justifications for otherwise anticompetitive conduct to be provable, indispensable, causally linked, and proportionate to the conduct, ${ }^{108}$ which makes the relevant claim to be construed "in such narrow terms ... that one wonders when it will be used at all." 109 The sentiment that justifications and efficiencies are not easily proven is shared in the United States as well. As Kattan notes "even today, one must search far and wide to find a case in which efficiencies, described and analyzed as such, trumped an anticompetitive story." ${ }^{110}$ Much like in the European Union, the problem is that once conduct has been found to have a measure of anticompetitive effects, courts and regulators are hesitant to tolerate it in the face of alleged justifications and efficiencies. ${ }^{11}$

In the end, sensing that efficiencies and justifications are not taken seriously by courts and regulators, firms have ceased relying on them as an argument to support their positions and rely instead on other aspects of the monopolization offense. These include the absence of

\footnotetext{
${ }^{106}$ Loewenthal generally remarks that " $[\mathrm{h}]$ ardly a case has gone by before the European Courts dealing with Article 82 that has not made some mention of 'objective justification.' It is therefore surprising to find that in not a single instance has either Court specifically applied this defense in favour of a dominant undertaking alleged to have infringed that provision by the Commission." Paul-John Loewenthal, The Defence of "Objective Justification" in the Application of Article 82 EC, 28 World Competition 455, 456 (2005).

${ }^{107}$ Friederiszick \& Gratz, supra note 105, at 685.

${ }^{108}$ Commission Guidelines, supra note 74 .

${ }^{109}$ Albertina Albors-Llorens, The Role of Objective Justification and Efficiencies in the Application of Article 82 EC, 44 Соммоn Мкт. L. Rev. 1727, 1758 (2007).

${ }^{110}$ Joseph Kattan, The Role of Efficiency Considerations in the Federal Trade Commission's Antitrust Analysis, 64 Antitrust L.J. 613, 613 (1996).

${ }^{111}$ Id. See also United States Dept. of Justice \& Fed. Trade Comm'n, Horizontal Merger Guidelines, I 10 (2010) (stating that "efficiencies are difficult to verify and quantify" and "efficiency claims will not be considered if they are vague, speculative or otherwise cannot be verified by reasonable means"), https://www.justice.gov/atr/horizontal-merger-guidelines08192010\#10
} 
anticompetitive effects or market power. In their survey, Friederiszick and Gratz noted that only " 47 percent of recent 102 TFEU cases an efficiency defense or other justification was put forward and reported. We consider this number to be low given that anticompetitive behavior and justifications are intrinsically linked in Article 102 TFEU cases." 112

When firms forego efficiencies and justifications as useless argumentation, it may be time to reconsider whether they should remain as universal requirements to define normal competition. A standard that is so hard to satisfy ends up trapping firms-especially successful firms who risk antitrust action. The tragedy of the successful firm is that it is confined either to patently innovative conduct that easily meets the on the merits requirement or patently risk-free conduct that will allow it to escape antitrust scrutiny. Anywhere between these two extremes is dangerous territory for dominant firms.

The counterargument here is that tests that rely on justifications and efficiencies are not badly designed-they are merely poorly executed. Efficiencies and justifications are some of the right metrics to use, but the challenge is how to better recognize and accept them. This is a fair point, and if it can be done, it solves this particular problem. However, one should question whether, even after decades of familiarization, courts and regulators are better equipped to identify and accept justifications and efficiencies. ${ }^{113}$ Business practices keep evolving and along with them potential justifications. Business practices and innovation will always be one step ahead of the law, and cautious courts and regulators will always be somewhat resistant to novel firm claims. ${ }^{114}$ Even if it is easier to identify potential justifications and efficiencies that are grounded in economic analysis, including the version of industrial organization endorsed by the Chicago School, it is doubtful that judges and regulators are well positioned to assess justifications and efficiencies that are grounded in other disciplines, such as technology, which is an increasingly defining aspect

\footnotetext{
${ }^{112}$ Friederiszick \& Gratz, supra note 105, at 687 (citing support from additional scholars).

${ }^{113}$ See Michael R. Baye \& Joshua D. Wright, Is Antitrust Too Complicated for Generalist Judges? The Impact of Economic Complexity and Judicial Training on Appeals, 54 J.L. \& Econ. 1 (2011); Geoffrey A. Manne \& Joshua D. Wright, Innovation and the Limits of Antitrust, 6 J. Comp. L. \& ECON. 153, 162 (2010).

${ }^{114}$ Frank H. Easterbrook, The Limits of Antitrust, 63 Tex. L. Rev. 1, 5 (1984) (stating that "[w]isdom lags far behind the market").
} 
of how companies conduct themselves in the market. ${ }^{115}$ Therefore, while making courts and regulators more responsive to claims of legitimate business justifications and efficiencies would increase the appeal of competition on the merits, this solution may not be feasible, and it does not address the remainder of the problems explained herein.

\section{Indeterminacy and Manipulation of Business Justifications and Efficiencies}

A third problem with always requiring a showing of legitimate business justifications or efficiencies is that these concepts have indeterminate content and can be manipulated. This reduces their reliability and consequently increases the error cost of the tests that rely on them.

The problem has its roots in the inability of the antitrust community to agree on the goals of antitrust law, which is a necessary step to determine the prescriptive content of the law. ${ }^{116}$ When one chooses to focus on legitimate business justifications and efficiencies, one essentially asks what kind of justifications and efficiencies should be accepted by antitrust law as compatible with its spirit and goals. Only those justifications and efficiencies that are aligned with the goals of antitrust law should be accepted. Unfortunately, disagreement besets this point, leaving firms, courts, and regulators free to choose what best fits their interests or preconceptions. ${ }^{117}$ In turn, reliance on a protean concept undermines the endeavor of determining normal competition.

The various proposed goals of antitrust law are by now well documented. Bork, for instance, based on a historical analysis, argued that antitrust law has only one concern-to increase economic efficiencyand he rejected sociopolitical goals such as combating big businesses, protecting small competitors, or wealth redistribution. ${ }^{118}$ If a firm managed to achieve economies of scale so extensive that it could drive

\footnotetext{
${ }^{115}$ See, e.g., Konstantinos Stylianou, Systemic Efficiencies in Competition Law: Evidence from the ICT Industry, 12 J. Comp. L. \& Econ. 557 (2016) (discussing unaccounted efficiencies in large technical systems).

${ }^{116}$ Robert Bork famously stated that "[a]ntitrust policy cannot be made rational until we are able to give a firm answer to one question: What is the point of the law-what are its goals? Everything else follows from the answer we give...." See Robert Bork, The Antitrust Paradox: A Policy at War with Itself 50 (1978).

${ }^{117}$ Marina Lao, Ideology Matters in the Antitrust Debate, 79 AnTitrust L.J. 649 (2014).

${ }^{118}$ Robert Bork, Legislative Intent and the Policy of the Sherman Act, 9 J.L. \& Econ. 7 (1966).
} 
competitors out of the market, Bork's version of antitrust would see this as normal competition and would allow it, even in the face of subsequent exploitation of consumers by the successful firm. Bork's view is not uniformly accepted. For other scholars-also relying on an analysis of antitrust's original intent-legitimate business justifications and efficiencies would have to be tied primarily to consumer welfare, which does not fully overlap with economic efficiency. ${ }^{119}$ Under this view, for example, the maintenance of price competition achieved through the protection of less efficient competitors, who would otherwise be driven out, could take priority over economic efficiency narrowly construed. Professor Fox agrees that efficiency is a primary consideration, but she takes a broader view of it to encompass the maintenance of "an environment congenial to mavericks and upstarts; an environment that induces firms to be rivalrous, to seek new ways to reduce their own costs, and to vie to meet buyers' wants." ${ }^{120}$ In that light, legitimate competition would be the kind that does not threaten the competitive process and addresses consumer demand.

The problem here is that firms can make a reasonable argument that the business practice they want to defend complies with one or more versions of the goals and spirit of antitrust law. For instance, a firm that prices above predatory pricing levels, but below its profit maximizing price at a level that deters entry, can legitimately claim that it abides by the version of antitrust law that prioritizes low consumer prices in the short term. However, by inhibiting the emergence of competition, it does not promote the goal of sustaining the competitive process, and therefore it fails another version of antitrust law. ${ }^{121}$

Surely, courts can decline to adopt the firm's preferred version of normal competition, but to the extent that multiple versions exist, antitrust law's deterrent message of what is forbidden in the market is diluted and

\footnotetext{
${ }^{119}$ John B. Kirkwood \& Robert Lande, The Chicago School's Foundation Is Flawed: Antitrust Protects Consumers, Not Efficiency, in How the Chicago School Overshot the Mark: The Effect of Conservative Economic Analysis on U.S. Antitrust 89 (Robert Pitofsky ed., 2008).

${ }^{120}$ Eleanor M. Fox, The Efficiency Paradox, in How the Chicago School Overshot the Mark: The Effect of Conservative Economic Analysis on U.S. Antitrust 77 (Robert Pitofsky ed., 2008).

${ }^{121}$ See Donald F. Turner \& Phillip E. Areeda, Predatory Pricing and Related Practices Under Section 2 of the Sherman Act, 88 Harv. L. Rev. 697, 705-06 (1975).
} 
inevitably potentially ignored. It cannot be expected that firms will reject a viable business plan because it somehow harms competition according to one test, but not necessarily another-particularly in a world where naturally "executives may think no further than 'let's get more business.",122

The ambiguity concerning which business justifications and efficiencies constitute normal competition opens the door for manipulation of the concept. Once firms choose which version of normal competition serves their interests, they have an advantage over prosecutors and regulators seeking to prove their case, because it is the internal operation of the firm that generates efficiencies and explains business conduct, and no one knows the internal operation of the firm better than the firm itself. ${ }^{123}$ Indeed, it is virtually impossible for any external observer to have more information about the internal working of firms than firms themselves, and therefore firms will always be in a position to package their actions in a way that maximizes the appearance of legitimacy and efficiency. ${ }^{124}$ They may very well fail, as nothing compels courts and regulators to endorse firms' positions. But the point here is not that firms will always manage to convince courts and regulators of their views, taking advantage of the information asymmetry; rather, if courts and regulators rely exclusively on subjective and internal-to-the-firm metrics to determine normal competition, they are vulnerable to manipulation.

To counter this risk, courts and regulators can become suspicious of firms' claims and raise the level of scrutiny to ensure that procompetitive justifications and efficiencies do exist. While possible, this may result in a prohibitively high threshold, a problem identified just above. Like Jason caught between the Symplegades, courts and regulators find themselves

\footnotetext{
${ }^{122}$ Barry Wright Corp. v. ITT Grinnell Corp., 724 F.2d 227, 232 (1st Cir. 1983).

${ }^{123}$ Philip Lowe, Consumer Welfare and Efficiency-New Guiding Principles of Competition Policy?, 13th International Conference on Competition and 14th European Competition Day, at 8 (2007) (stating that "[s]ometimes a complainant will help us [the Commission] to put together some arguments, but he will usually have more limited access to information than the defendant, the dominant undertaking. This makes it very challenging to gauge in a specific case the consequences, efficiencies or others, of a challenged practice."), https://ec. europa.eu/competition/speeches/text/sp2007_02_en.pdf.
}

${ }^{124}$ Anticipating antitrust scrutiny, firms can take steps to shroud their practices in a veil of legitimacy. See Oliver Heil \& Arlen Langvardt, The Interface Between Competitive Market Signaling and Antitrust Law, 58 J. Мктя. 81, 93-94 (1994). 
in a situation where they need to balance between avoiding manipulation and avoiding excessive strictness. ${ }^{125}$ The former undermines the quality of judicial and administrative enforcement; the latter disrupts industry operation. It is in this context that incorporating an additional external to the firm element—commonness-can help better calibrate enforcement intensity.

\section{The Commonness Test}

So far, I have established two claims that set the groundwork for the commonness test. First, that all nonvacuous monopolization tests revolve around competition on the merits, which requires a showing of legitimate business justifications or efficiencies. Second, that despite its universal acceptance, competition on the merits suffers unaccounted for weaknesses, which make it misaligned with market realities, unrealistically hard to satisfy, and easy to manipulate.

To correct for these weaknesses, what is suggested here is the adoption of an additional proxy-a practice's commonness in the market-which would take precedence over, but not replace, business justifications and efficiencies in distinguishing normal competition from abusive, monopolizing competition. It will be argued that incorporating the commonness element as a precheck to business justifications and efficiencies enhances the inquiry of which practices should constitute normal competition and can therefore escape monopolization liability. To prove this point, the commonness test is analyzed relative to existing tests in an error cost framework, namely, a framework that considers which test delivers better results under conditions of uncertainty. This is necessary, because the decision regarding the legality of practices depends on a finding of which practices promote the chosen goals of antitrust law and which do not, something that is impossible to determine with certainty. Therefore, the function of the relevant tests is to minimize errors when choosing between the two outcomes.

\footnotetext{
${ }^{125}$ The Symplegades were a pair of rocks in Greek mythology that clashed together every time a ship sailed through. Jason and the Argonauts successfully navigated through them, after which point the Symplegades remained forever open. The allegory is used to describe difficult predicaments, often between two equally bad choices. See William F. Pickard, The Symplegades, 34 GreEce ANd Rome 1 (1987).
} 
Some might argue that the commonness of a business model is already taken into account, and therefore the commonness test does not add anything new. As reasonable as this might sound, it is not accurate, because the level of generality at which courts and regulators examine the role of business practices is very high. For example, in Microsoft the D.C. Circuit considered the question of whether and how "technologically dynamic markets" merit different antitrust analysis, ${ }^{126}$ but this is not the same question as whether Microsoft's conduct was justified with regard to how firms compete in technologically dynamic markets.

Similarly, in Irish Sugar the CJEU alluded to taking into account market features by stating that normal competition and abuse of dominance are judged "on the basis of the transactions of commercial operators" and "it is necessary to consider all the circumstances," but it stopped short of specifying these elements and in particular of tying them to the commonness of business practices. ${ }^{127}$ In British Airways, that airline argued that its practices were common in the industry, but it did so in relation to a nondiscrimination argument, not a normal competition argument. ${ }^{128}$ The argument was in any case rejected. On the other hand, in Tampa Electric Co. v. Nashville Coal Co. the Supreme Court appeared to consider common business models by acknowledging that in utilities markets long-term exclusive supply contracts may be necessary, ${ }^{129}$ and this may be the closest the Court has come to incorporating commonness within its antitrust jurisprudence.

In short, the standard practice of the industry is still not sufficiently accounted for. The proposed reconceptualization gives commonness of the challenged business practice a centerpiece position. As this is a major departure from current antitrust law analysis, a step-by-step description is required. The following section first recasts normal competition/ monopolization tests as error tests, then explains how the commonness test works, and finally compares results with existing tests to show how the commonness test can deliver welfare-enhancing results. However, the value of the commonness test is not simply to serve as a standalone

\footnotetext{
${ }^{126}$ United States v. Microsoft Corp., 253 F.3d 34, 49 (D.C. Cir. 2001).

${ }^{127}$ Case T-228/97, Irish Sugar PLC v. Comm'n, 1999 E.C.R. II-2975, ๆף 111 and 114.

${ }^{128}$ Case T-219/99, 2003 E.C.R. II-5925, ๆ 59.

${ }^{129} 365$ U.S. 320 (1961).
} 
alternative test. It is also to highlight commonness as a pertinent parameter of normal competition, even if one is not prepared to make commonness the centerpiece parameter.

\section{A. Monopolization Tests as Error Tests}

Part I presented the various versions of monopolization tests available. Yet, little guidance can be sought in courts' reasoning, since courts never explain why they choose one definition of monopolization over another. They just select one, usually bound by precedent, and then proceed to apply it to the case facts. Scholarly discussions, while often good at arguing in favor of or against specific tests, generally fail to explain the superiority of their choice relative to other tests. Scholarly discussions often explain why their preferred or proposed test is better to distinguish between pro- and anticompetitive conduct, but they do not discuss the question of better in relative terms. Since they all acknowledge that an error margin and a degree of uncertainty in their premises and assessment is inevitable, ${ }^{130}$ what metrics do they use to compare their results to those of other tests? ${ }^{131}$ Without a framework to compare expected results of adopting different tests, we can have a discussion of the merits and shortcomings of different tests, but we cannot have a meaningful way of deciding among them.

It is suggested here that a useful and necessary way to think about monopolization tests is as an error cost assessment. ${ }^{132}$ Any inquiry into the legitimacy of business conduct is essentially an attempt to predict the effects of the challenged conduct on the chosen objectives of antitrust law to maximize welfare under conditions of imperfect information. ${ }^{133}$

\footnotetext{
${ }^{130}$ See, e.g., Elhauge, supra note 7, at 316, 320. See also Salop, supra note 62, at 313, 343; Werden, supra note 66 , at 320-22.

${ }^{131}$ Salop's consumer welfare test analysis stands as an exception, insofar as it uses a framework similar to the one advocated for herein. See Salop, supra note 62, at 343.

${ }^{132}$ Of the relevant literature that discusses error cost frameworks in antitrust, only Evans and Padilla (and Salop) use them to decide among specific normal competition tests; the rest use them to analyze false positive and false negative errors in antitrust generally. See Evans and Padilla, supra note 22; Salop, supra note 22.

${ }^{133}$ C. Frederick Beckner III \& Steven C. Salop, Decision Theory and Antitrust Rules, 67 ANTItrust L.J. 41 (1999); James C. Cooper et al., Vertical Antitrust Policy as a Problem of Inference, 23 Int'l J. Indus. Org. 639 (2005); Alan Devlin \& Michael Jacobs, Antitrust Divergence and the Limits of Economics, 104 Nw. U. L. Rev. 253 (2010).
} 
Ideally, when reviewing business conduct we would seek to have perfect information on how the challenged conduct affects welfare. If the effect is neutral or positive, then we would allow the practice, and if the effect is negative, we would ban the practice. But reality is plagued with indeterminacy, human capacity is limited by bounded rationality, and full direct observation of effects is impossible. ${ }^{134}$ We cannot know with certainty the effects of business conduct, because it is impossible to authoritatively determine the scope of the effects, and the effects are impossible to accurately quantify. ${ }^{135}$

In this light, monopolization tests become an exercise of choice under conditions of uncertainty. Therefore, all tests are bound to deliver a measure of false results, either in the form of false positives or in the form of false negatives. In turn, the choice of which test is preferable is a choice about minimizing error cost. ${ }^{136}$ In other words, once we accept that all these tests can do is help courts and regulators estimate whether a certain business practice promotes or undermines welfare (or any other chosen goal of antitrust), the focus shifts to developing a test that delivers estimates that are as close to the actual, but not fully observable effects as possible.

This conceptualization of monopolization tests has an important implication-it makes it necessary to examine and decide among tests through an error framework. ${ }^{137}$ An error framework compares tests on the basis of the decision-making factor they employ, and determines which test has the lowest error footprint based on a number of relevant factors. Without it, any comparison and any decision among tests is anecdotal. Seen through an error framework, monopolization tests are tests that use a proxy-the decision-making factor to help us estimate or predict the effects of the challenged practice on consumer

\footnotetext{
${ }^{134}$ Joseph F. Brodley, The Economic Goals of Antitrust: Efficiency, Consumer Welfare, and Technological Progress, 62 N.Y.U. L. Rev. 1020, 1028-30 (1987). On the topic of bounded rationality, see Brian W. Arthur, Inductive Reasoning and Bounded Rationality, 84 Am. Econ. Rev. 406, 406 (1994).

${ }^{135}$ See Beckner \& Salop, supra note 133, at 49-52; Manne \& Wright, supra note 113, at $158-60$.

${ }^{136}$ The design of any legal rule or standard can be seen as a way to minimize error. See Isaac Ehrlich \& Richard A. Posner, An Economic Analysis of Legal Rulemaking, 3 J. Legal Stud. 257 (1974).
}

${ }^{137}$ See Salop, supra note 62 , at $343-45$. 


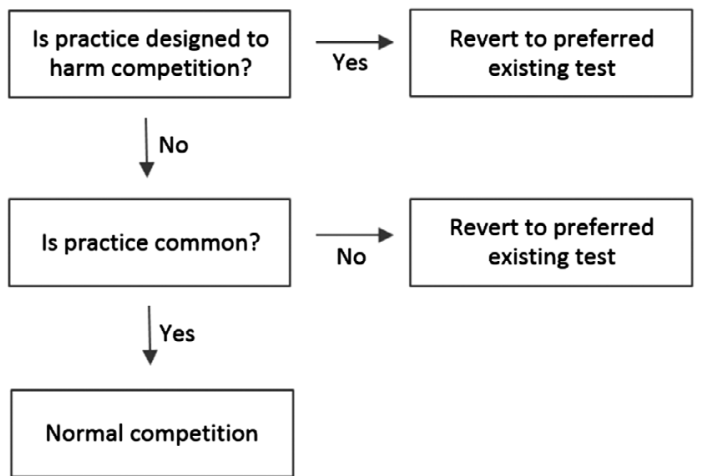

FIGURE 1. The Commonness Test.

welfare. ${ }^{138}$ Everything else equal, the closer that estimate is to the actual welfare effects under conditions of perfect information, the smaller the error footprint, and the better the test. The various tests differ from each other in that they adopt different proxies, and therefore the best test is the one that employs the proxy that leads to the smallest error footprint.

As discussed above, existing tests have converged around the proxy of legitimate business justifications and efficiencies. The following section explains why introducing commonness as a priority proxy can enhance the results of the normal competition versus monopolization heuristic.

\section{B. Description and Overview of the Commonness Test}

The reconceptualization of monopolization proposed here centers on the idea that the commonness of a business practice in the market in which it occurs should be examined before considering the question of whether the practice is supported by legitimate business justifications and efficiencies. ${ }^{139}$ The commonness test, therefore, builds on and complements, rather than replaces, existing tests, because if a practice fails the commonness check, it still must pass one of the existing tests. The proposal is

\footnotetext{
${ }^{138}$ While not universally accepted, welfare protection as antitrust's predominant goal is today's dominant view. See Sullivan ET AL., supra note 1.

${ }^{139}$ Before examining commonness, the test also requires that the challenged practice is not designed to harm competition, a condition that is examined infra Part III.C.2.
} 
predicated on an error framework analysis that shows that giving precedence to commonness results in a smaller error footprint compared to the exclusive use of business justifications and efficiencies.

The commonness test comprises two steps (see Figure 1). The first step is to ask whether the practice under question is designed to harm competition-which is not the same as being likely to harm competition. If it is not designed to harm competition, then the test asks whether the business practice under scrutiny is common in the market in which it occurs. If the practice is common and not designed to harm competition, then it should be considered normal competition and therefore not be deemed illegal monopolization without requiring a showing of business justifications or efficiencies, as is required under the current tests. If it is not common, then the examiner may revert to the test of choice from the ones currently available. The commonness test therefore serves as a precheck before any of the existing tests are applied. Since commonness is a matter of degree, there is no cut-off point after which the commonness test fully takes over. Rather, the more common a practice is, the less important business justifications and efficiencies become, and vice versa.

Since the investigation into commonness precedes the investigation into justifications and efficiencies, the integration of the commonness parameter results in the clearance of practices that exhibit zero, weak, or unclear legitimate business justifications or efficiencies but that are not designed to harm competition. It is evident that incorporating the commonness parameter does not materially affect practices that come with clear and provable justifications and efficiencies, since these would likely pass existing tests anyway. Its effect is more pronounced in that it guards against outlawing practices that do not conform to competition on the merits as understood by current tests. This should not be read to mean that the test shields harmful practices, since, as mentioned in Part II.A, the fact that firms may be found not to engage in competition on the merits does not mean that their conduct is harmful to competition. Moreover, the test forbids anticompetitive motivations, which serves as an additional backstop.

\section{Elements and Assessment of the Commonness Test}

A number of issues concerning the structure and function of the test need to be addressed here in more detail. First, how should commonness be defined and why is it a good proxy for legitimate competition? 
Second, how can practices that are designed to harm competition be identified, and why does this parameter matters? Third, as seen through an error test framework, does the added commonness parameter enhance the heuristic of distinguishing between normal competition and monopolization, and if it does so, why? These issues are addressed in sequence below.

\section{Choice and Definition of Commonness}

The element of commonness is chosen to respond to the shortcomings of various competition on the merits tests. It does so by acknowledging and justifying practices that are aligned with business and market realities, and by serving as an external-to-the-firm parameter that cannot be unilaterally manipulated. ${ }^{140}$

The main premise is that the observation of commonness of a business practice provides a strong indication that the practice is well adapted to the needs and features of the relevant market, because multiple firms rationally and independently ${ }^{141}$ think that the practice ensures their survivability. Firms do not compete in a vacuum, and they do not compete in the same way across markets. Their practices are shaped by the context in which they compete as a response to market characteristics and to competition from other firms. ${ }^{142}$ Both internal capabilities of the firm and environmental factors shape firm conduct, and in that sense firm conduct is a reflection of the firm's best response-given its capabilitiesto the external industry conditions and characteristics the firm takes for granted. ${ }^{143}$

Numerous practices that have been challenged by law are supported by managerial economics on the basis of the specific characteristics of

\footnotetext{
${ }^{140}$ Collective manipulation through tacit coordination is theoretically possible. The error cost here would be discounted by the fact that eventually such arrangements would likely fail the test as being "designed to harm competition," in which case the examiner would revert to any of the existing tests (see Part III.C.2).

${ }^{141}$ As mentioned, normal competition is a concept that applies in the monopolization/abuse of dominance domain, not restraints of trade/agreements.

${ }^{142}$ Michael Porter, The Competitive Strategy: Techniques for Analyzing Industries and Competitors (2004); Jay B. Barney, Types of Competition and the Theory of Strategy: Toward an Integrative Framework, 11 Acad. Mgmt. Rev. 791 (1986).

${ }^{143}$ Richard R. Nelson, Why Do Firms Differ, and How Does It Matter?, 12 Strategic Mgmt. J. $61(1991)$.
} 
given markets. For example, in markets characterized by large upfront investments and low marginal costs, price discrimination is accepted as an advisable business practice. ${ }^{144}$ In industries characterized by network effects, displacement often comes in successive waves of dominant firms, and therefore it is natural for firms to wish to dominate the market for the duration of their transient reign. ${ }^{145}$ And depending on the stage of evolution of the industry, firms may find it necessary to vertically integrate or disintegrate to respond to market characteristics. ${ }^{146}$

Such common business models and practices may appear anticompetitive by current standards, but their propagation across firms can indicate that they are necessary to capture value, without which firms cannot exist. Professor Teece has explained at length how restrictive business arrangements of the kind antitrust law scrutinizes may be necessary to allow firms to appropriate the value they generate when commercialization requires working with complements. ${ }^{147}$ Without arrangements to exercise control, value may be captured by the complements, rather than the firm that enables the complements. For example, Google's practice of showing comparative shopping results sourced by itself and not by third parties on the general results page was motivated by the desire to capture the value of its search services, instead of letting it dissipate to complementary services. Google explained in Google Search that it was standard practice for search engines to compete in the market "by showing their results, not results from other services [since] users do not expect search services to provide results from other services," and that its conduct was necessary to allow it "to monetise space on its general search results pages." 148 The Commission disagreed, counterarguing that a nondiscrimination requirement "does not generally prevent [Google]

\footnotetext{
${ }^{144}$ Carl Shapiro \& Hal R. Varian, Information Rules: A Strategic Guide to the Network ECONOMY 37-39 (1999).

${ }^{145}$ Joseph Farrell \& Paul Klemperer, Coordination and Lock-In: Competition with Switching Costs and Network Effects, in III Handbook of Industrial Organization (Mark Armstrong \& Robert Porter eds., 2007).

${ }^{146}$ See, e.g., Michael G. Jacobides, Industry Change Through Vertical Disintegration: How and Why Markets Emerged in Mortgage Banking, 48 Acad. MGмт. J. 465 (2005) (discussing the factors of (dis)integration in the banking market).

${ }^{147}$ Teece, supra note 80.

${ }^{148}$ Google Search, Commission Decision 2017 O.J. (C 4444), ๆ 657 (emphasis added).
} 
from monetising its general search results pages. Google can choose the specific measures through which it intends to comply with [the Commission's decision] and the possible measures Google might take do not preclude the monetisation of its general search results pages when making this choice." 149

None of the above is to say that antitrust law's interests should always be the same as common business interests. It is indeed possible that some common business models will be welfare reducing, and therefore run afoul of antitrust law. Because of the error margin in normal competition tests, this possibility exists regardless of which test one chooses. Whether the commonness test delivers better results than existing tests is discussed in Part III.C.3. Moreover, at least according to one historical understanding of abuse, a practice cannot be abusive if it can also be exercised by nondominant firms. ${ }^{150}$ While this approach applies even in cases where a practice is exercised by one nondominant firm, the logical extension is that if more than one nondominant firm engages in a practice the practice is by definition not abusive and therefore normal competition.

The second way commonness enhances the heuristic process of distinguishing between normal competition and monopolization is by serving as an external-to-the-firm parameter. Commonness is assessed by looking at the market, not inside the firm, and therefore does not depend on the challenged firm's own understanding of commonness. This guards against manipulation, ${ }^{151}$ because commonness is a question of fact, not law, and is not susceptible to predispositions and ideology, like legitimate business justifications or the elusive factor of efficiencies.

Some definitional elements of commonness further help justify its choice: how is commonness measured, what is the referenced practice, and how is the market defined? Commonness refers to how widespread a challenged business practice occurs in the market. It should be expected that there is no fixed percentage, over which a practice is considered common, as this would be arbitrary. One solution would be to specify strata of certainty similar to Judge Hand's guidance on monopoly

\footnotetext{
${ }^{149} I d$. at $\uparrow 664$.

${ }^{150}$ Aкman, supra note 25, at 319 .

${ }^{151}$ As stated earlier, collective manipulation through tacit coordination is theoretically possible.
} 
levels in United States $v$. Aluminum Co. of America, where he opined that "ninety percent is enough to constitute a monopoly; it is doubtful whether sixty or sixty-four percent would be enough; and certainly thirty-three per cent is not." 152

The equivalent formulation in the commonness test would be to say that above a certain percentage, a practice is always considered common, below a certain percentage a practice is never considered common, and then acknowledge that there is a grey zone, wherein the specifics of the market are also determinative. This is not a preferred solution in the case of the commonness test, both because it is impractical and because of its distorting effects. Unlike market share calculation, where the measured element is readily identifiable as sales, units, or volume that are relatively easy to measure, determining whether all, or a large representative sample of, businesses engage in the practice that is being challenged would be cumbersome. This is because evaluative judgments would be required. Moreover, it would not be informative because it would compare disparate situations. To the extent that different companies are positioned differently in the market, their adoption of the same business practice may not necessarily be instructive as to what is "normal" in the industry.

Instead, commonness should be assessed by reference to how widespread a business practice is among close competitors of the challenged company. The circle of close competitors indicates similarly situated firms and therefore a more meaningful point of comparison. ${ }^{153}$ Antitrust law acknowledges that, because the vast majority of markets encompass differentiated products and services, competitive closeness rather than mere quantitative measurements provides a better view of the challenged company's positioning in the market. ${ }^{154}$ Therefore, when the commonness test seeks to align what is competitively legitimate with what is competitively common, the reference point of commonness should be

\footnotetext{
${ }^{152} 148$ F.2d 416, 424 (2d Cir. 1945).

${ }^{153}$ Thomas Buettner, Closeness of Competition from an Economic Perspective, 7 J. Eur. Comp. L. \& Prac. 690 (2016); David Levy \& James Reitzes, Anticompetitive Effects of Mergers in Markets with Localized Competition, 8 J.L. Econ. \& Org. 427 (1992).

${ }^{154}$ U.S. Dep't of Justice \& Federal Trade Comm'n, Horizontal Merger Guidelines § 4 (2010), https://www.justice.gov/atr/horizontal-merger-guidelines-08192010\#10; Council Regulation 139/2004 (EC) of 20 January 2004 on the Control of Concentrations Between Undertakings, 2004 O.J. (L. 24) ๆ 28.
} 
commonness among those companies that are competitively similar. This also makes the test manageable as it limits the inquiry to a small number of competitors, rather than the potentially very large number of all companies in the market.

Not all markets are conducive to a competitive closeness type of analysis. The test obviously works best in large markets with numerous participants who span a spectrum of competitive positioning. The test also works in oligopolistic markets as long as some competitors exhibit competitive closeness. For instance, in an oligopolistic market of five comparable companies each having around twenty percent market share, a business practice that is adopted by four of them can be considered common. In a more complex example, in the Google Android case, Google's practice of bundling applications on its mobile operating system was identical to what Apple, Microsoft, and Blackberry did. Even though the market comprised essentially only four players (with smaller competitors accounting for less than two percent of the market at all times), and even if their market shares were markedly different-with Microsoft never achieving more than five percent, while Android, at the time of the case, came closer to sixty percent-the overall technological proximity of these firms and their overall capabilities and size outside of the mobile operating system market could well qualify them as close competitors. ${ }^{155}$ The Google Android case also shows that even in highly innovative and relative young markets, there may still be a sufficient number of close competitors to make the test applicable.

A related example can be sourced from the failed early litigation against MySpace and Facebook, whereby the two dominant social networks were accused of exclusionary conduct by preventing competitors from using their platform. ${ }^{156}$ Even though at the time of litigation the two companies were only a few years old, their noninteroperable business model was sufficiently discernible to establish a class of close competitors, which at the time included Friendster, hi5, Orkut, and others. It is, of course, entirely possible that there will be industries where close

\footnotetext{
${ }^{155}$ See Konstantinos Stylianou, Exclusion in Digital Markets, 24 Мıсн. теLEcomm. \& Tech. L. Rev. 181, 202-10, 243-51 (2018) (discussing technological proximity and the ease of cross-market entry).

${ }^{156}$ LiveUniverse, Inc. v. MySpace, Inc., 304 Fed. App'x 554 (9th Cir. 2008); Facebook, Inc. v. Power Ventures, Inc., No. C 08-5780 JF (RS), 2009 WL 3429568 (N.D. Cal. 2009).
} 
competitors do not exist or do not adopt the challenged practice, and in these cases the commonness test is unhelpful. A final possibility involves industries where only nonclose competitors adopt the challenged practice. While this could still be indicative of commonness, it is methodologically sounder to consider the test inapplicable in these instances.

Commonness, therefore, is a composite index that relies on a quantitative measurement within a qualitatively selected subsegment of the market comprised of a challenged company's close competitors. Competitive closeness is traditionally identified by looking at who companies consider to be their main competitors. Evidence includes companies listed in their annual reports, surveys among other companies in the market, bidding trends, and economic analysis (including natural experiments). ${ }^{157}$ Ultimately, the larger the assessed base of close competitors and the higher the percentage of adoption within that base, the more robust the result. In that sense, the implications of the commonness test are a matter of degree-the more common a practice, the less important business justifications and efficiencies become. This kind of sliding scale ensures that the commonness parameter is integrated smoothly into existing tests and takes over only insofar as its findings become robust.

One last definitional element remains-how to properly define the practice and the market in which the practice occurs. In Google Android the question could be phrased, in ascending order of generality, whether it is common to bundle an application with other applications, to bundle apps in the Android market, to bundle apps in the mobile software market, to bundle apps in the software market, to bundle products and services in the computer industry market, or to bundle products and services generally. The level of generality affects the scope within which the investigation seeks commonness. The answer would usually be obvious from the scope of the inquiry itself as launched by courts and authorities. For example, in Google Android the investigation focused, inter alia, on bundling between Google Play and other mobile apps. ${ }^{158}$

Market definition will then reveal the boundaries within which investigators will look for commonness. It is beyond the purpose of the test to feed into the process of market definition, but as a general matter, it seems right

\footnotetext{
${ }^{157}$ Malcolm B. Coate, The Use of Natural Experiments in Merger Analysis, 1 J. AnTitrust ENForCEMENT 437 (2013).

${ }^{158}$ Google Android, Commission Decision 2019 O.J. (C402) 19-22, ๆ 4.
} 
to focus on the practice at the product or service level of abstraction in the market in which the practice occurs as a primary market. This is because the test aims to give weight to the factors that most directly shape the method of competition of firms-predominantly, their immediate market surroundings in the relevant product or service market. Broader investigation beyond the market in which the practice occurs can be appropriate if the conditions underlying certain behavior in secondary markets are similar to those in the primary market. For example, if we accept that long-term exclusive supply contracts in electricity supply markets can be a common practice, ${ }^{159}$ to the extent that an argument can be made that the electricity and water supply markets are similar because both are utilities markets, evidence of the commonness of long-term exclusive contracts in either of those markets can be used complementarily.

\section{Not Designed to Harm Competition}

Prior to investigating commonness, the test requires us to ask whether the challenged practice is designed to harm competition. If it is, the practice fails the test, and the examiner reverts to another test of their choice. If it is not, the examiner proceeds to investigate commonness. The utility and necessity of this step is obvious. It ensures that certain practices, no matter how common, will not qualify as normal competition given their pernicious nature as signaled by the fact that their success is predicated on harming competition. As a result of this step, companies cannot count on normalizing behavior that is designed to harm competition by adopting it en masse in an effort to subvert the commonness test, even if they do so independently from each other. If they do it in concert, they would most certainly be engaging an anticompetitive agreement. On the other hand, the test never filters out potentially procompetitive practices, because even if it erroneously catches a practice that is, in reality, not designed to harm competition (false positive), the result is that examiners revert to another test of their choice, as explained above.

Harm to competition is chosen here under the assumption that antitrust law aims to protect competition in order to serve the ultimate goal of safeguarding consumer welfare. ${ }^{160}$ Yet, even if one were

\footnotetext{
${ }^{159}$ See, e.g., Tampa Electric Co. v. Nashville Coal Co., 365 U.S. 320 (1961).

${ }^{160}$ Brodley, supra note 134. See also Alan Devlin, A Neo-Chicago Perspective on the Law of Product Tying, 44 Ам. Bus. L.J. 521, 524-30 (2007).
} 
to choose the protection of competitors (instead of the protection of competition) as the preferred proxy, ${ }^{161}$ the step could also be reformulated as "not designed to harm competitors." The protection of competitors, however, as the primary goal of antitrust law is a minority view.

It may appear that the questions of which practices are designed to harm competition (first step of the commonness test) and which practices are anticompetitive because they are monopolistic (the full commonness test) are one and the same. If that were the case, then this first step of the commonness test and the commonness test as a whole would be conflated. Despite this seeming logical circularity, the step of checking whether a practice is designed to harm competition is simpler and narrower in scope. It only aims to check for and filter out practices with the objective of harming competition, and therefore the elimination of competition is an integral part of the overall design. Situations where the elimination of competition is a by-product (rather than a design element) are not caught at this step.

'For instance, predatory pricing would fail this step, because a necessary premeditated component of profitable predatory pricing-and therefore part of the overall design-is below-cost pricing to eliminate competition first. ${ }^{162}$ Another example of a practice that would fail this step is Microsoft's actions to actively undermine Sun's implementation of Java on Windows, which had no other purpose but to taint Sun's Java compatibility. ${ }^{163}$ On the contrary, the development of a new product that can be profitable only if it is so effective that it excludes competitors would pass this step, because the elimination of competition comes as the consequence of the product's effectiveness, rather than as an intended aspect of its development. ${ }^{164}$ In the former case, the perpetrator takes affirmative steps toward the elimination of competition, whereas in the second case, the perpetrator accepts or even hopes for

\footnotetext{
${ }^{161}$ See Robert Pitofsky, Political Content of Antitrust, U. Penn. L. Rev. 1051, 1063 (1978) (discussing the distinction between protection of competition and protection of competitors).

${ }^{162}$ Patrick Bolton et al., Predatory Pricing: Strategic Theory and Legal Policy, 88 Geo. L.J. 2239, 2267 (2000).

${ }^{163}$ United States v. Microsoft Corp., 253 F.3d 34, 43 (D.C. Cir. 2001).

${ }^{164}$ See, e.g., OECD, supra note 24 , at 26.
} 
the elimination of competition but does not actively take steps that specifically aim at that.

The element of intent is clearly present here. The assessment considers the obvious structure of the challenged conduct as it appears to the reasonable observer, but also the intent and proffered justifications for the conduct. These are essential in understanding what the firm is aiming to achieve ${ }^{165}$ but do not need to be "legitimate" the same way existing tests understand them.

The role of intent in antitrust law analysis is controversial, but not in a way that affects the use of intent in the commonness test. Those who reject intent argue that a company's state of mind is irrelevant in the inquiry of what antitrust law should focus on. Further, the state of mind is also misleading since it is indistinguishable from legitimate and desirable competitive aggressiveness. ${ }^{166}$ Those who support examining intent argue that the dangers are overstated, and that it is essential to form a comprehensive opinion about the challenged conduct. ${ }^{167}$ Either way, the function of intent in existing competition on the merits tests is different from that in the commonness test. In existing tests, intent is used to assist to find a violation where effects are not fully established and may yield false positive errors. However, in the commonness test, intent only serves to determine whether the commonness test is applicable. Failing that step only results in the test declaring itself inapplicable, at which point examiners revert to an existing test of their choice. In that sense, the element of intent in the commonness test enhances the test's results but does not contribute to raising the error cost rate, as is the case in current tests. Therefore, any potential criticisms against the use of intent in current antitrust analysis are attenuated in relation to the commonness test.

\footnotetext{
${ }^{165}$ See Werden, supra note 66 , at $416-17$. This step is somewhat similar to the no economic sense test. However, the no economic sense test differs in that it does not distinguish between the elimination of competition as part of an intended design or as a consequence, and creates exceptions for conduct that is socially beneficial or enhances consumer welfare.

${ }^{166}$ Herbert Hovenkamp, The Monopolization Offense, 61 Оніо Sтате L.J. 1035, 1039 (2000). See also A.A. Poultry Farms, Inc. v. Rose Acre Farms, Inc., 881 F.2d 1396, 1402 (7th Cir. 1989).

${ }^{167}$ Ronald A. Cass \& Keith N. Hylton, Antitrust Intent, 74 S. CAL. L. Rev. 657 (2000); Marina Lao, Aspen Skiing and Trinko: Antitrust Intent and Sacrifice, 73 Antitrust L.J. 171 (2005).
} 
3. Commonness Versus Competition on the Merits in an Error Test Framework

The previous step filters out business practices that are hostile to the competitive fabric of the industry on account of the practices' intended design. Most practices, though, would not fall in this category, and would in any case fail existing tests as well. For all remaining practices, this section compares the results of making commonness the primary proxy for the monopolization test with the results of current tests, which employ legitimate business justifications and efficiencies as the exclusive proxy. The comparison is performed on the basis of an error cost framework, because, as explained in Part III.A, monopolization tests are essentially tests that attempt to minimize the error cost in estimating but never accurately observing the real welfare effects of business practices.

Stripped of all definitional issues and fine-tuning requirements, to make commonness the primary proxy of normal competition is to specify that that which is common and not designed to harm competition ought to be normal competition. This contrasts with the current belief that whatever is efficient ought to be normal competition and not monopolistic. This is an impermissible conclusion, because according to the classic is/ought fallacy one cannot directly derive an ought statement from an is statement. ${ }^{168}$ Is statements are factual-they describe empirical truths such as a practice is common in the market. ${ }^{169}$ Ought statements are evaluative-they reflect an opinion that relies on and presupposes a system of values such as a practice ought to be accepted as normal competition. ${ }^{170}$ The is/ought fallacy tells us that we cannot directly derive that practice $A$ ought to be normal competition from the statement that practice $A$ is common, absent a system of values that takes the form of a universal ought principle such as practices that are common ought to be accepted as normal competition. ${ }^{171}$

\footnotetext{
${ }^{168}$ This is originally attributed to David Hume, A Treatise of Human Nature (e-Book last updated Nov. 10, 2012). See also John R. Searle, How to Derive "Ought" from "Is," in The Is/ Ought Question 120 (Donald Hudson ed., 1969).

${ }^{169}$ Alan Gewirth, The "Is-Ought" Problem Resolved, 47 Proceedings and Addresses of the American Philosophical Association 34 (1973).

${ }^{170} I d$.; Donald Hudson, The "Is-Ought" Problem, in The Is/Ought Question 11 (Donald Hudson ed., 1969).

${ }^{171}$ Hudson, supra note 170 .
} 


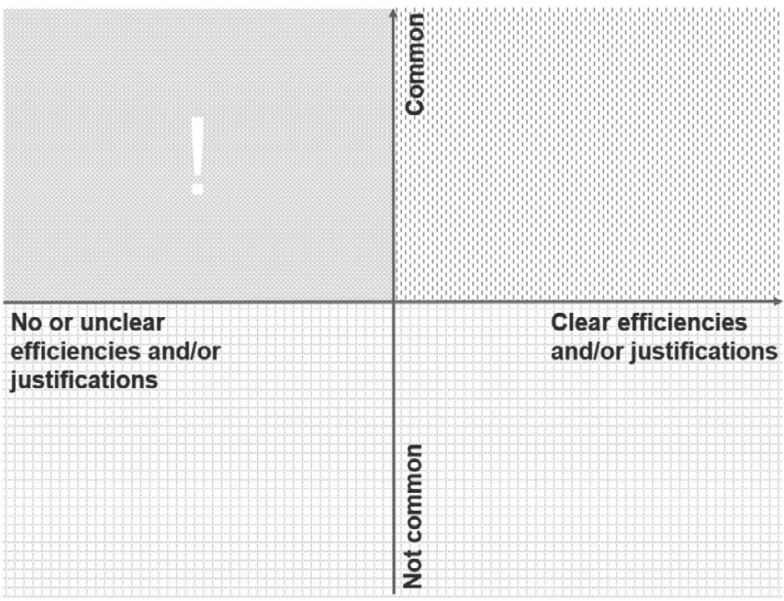

Existing and commonness tests can agree

Existing and commonness tests may differ

Commonness test inapplicable. Revert to preferred existing test

FIGURE 2. Interface of Existing and Commonness Tests.

The complete syllogism now looks like this: (1) practices that are common and not designed to harm competition ought to be accepted as normal competition (universal ought principle); (2) practice $A$ is common and not designed to harm competition (is statement); and (3) practice $A$ ought to be accepted as normal competition (particular ought judgment).

Existing tests also necessitate and do indeed come with their own universal ought principle in the form of practices that are supported by legitimate business justifications, or efficiencies ought to be accepted as normal competition. Since under conditions of uncertainty error is inevitable, to give precedence to commonness over competition on the merits as the universal ought principle, ${ }^{172}$ we do not need to establish that the commonness test yields perfect results—only that it yields better results than existing tests by helping reduce false positive and false negative errors.

In comparing the commonness test with existing competition on the merits tests, there are three possibilities (see Figure 2). The first is that a practice passes both the commonness test and existing tests-it is both common and exhibits business justifications and efficiencies. In that case

\footnotetext{
${ }^{172}$ Doing so would justify the universal evaluative statement, a necessary condition to derive an evaluative statement from other evaluative statements. See Gewirth, supra note 169.
} 
the two tests deliver similar results, so neither is superior. ${ }^{173}$ The second possibility is one in which a practice that under conditions of perfect information is welfare enhancing, would pass the commonness test, but would fail existing competition on the merits tests. This situation could arise due to the false positive susceptibility of competition on the merits tests identified in Part II.B. In this case the commonness test would deliver good results, but existing tests would deliver false positive results. They would wrongly indicate that a practice is welfare reducing when it is not, and therefore the commonness test should be preferred.

The third possibility is one by which a practice that under conditions of perfect information is welfare reducing, would pass the commonness test, but would fail existing competition on the merits tests. This is a scenario whereby the commonness test would deliver false negative results and would wrongly indicate that a practice is welfare enhancing when it is not. In these cases existing tests would deliver good results, and therefore the commonness test should not be preferred.

Under this setup of the commonness test and existing competition on the merits tests as error tests, the decision whether one should keep the commonness test depends on whether, based on the latter two possibilities, it is more welfare enhancing to tolerate the errors of the commonness test or those of existing tests.

As should be obvious from the exposition above, the commonness test is less susceptible to false positive errors than existing tests, since the commonness test never filters out procompetitive conduct. ${ }^{174}$ To the contrary, the commonness test is more susceptible to false negative errors, because of the higher standard competition on the merits tests employ compared to commonness. It is generally believed by Chicago School proponents that it is better to tolerate false negatives than false positives, because the wrongful condemnation of procompetitive conduct results in a permanent loss of the conduct's benefit, whereas the wrongful permission of anticompetitive conduct will be short-lived as markets are

\footnotetext{
${ }^{173}$ If we could have perfect information on the actual (rather than the estimated) effects of the challenged practice, we may discover that both tests were right to allow the challenged practice or that both tests were wrong. In any case, since both delivered similar results, this possibility is inconclusive.

${ }^{174}$ The only way for procompetitive conduct to fail the commonness test is to not be common, in which case the commonness test reverts to existing tests.
} 
believed to be self-correcting. ${ }^{175}$ The commonness test would accordingly benefit from such argumentation.

This line of thinking has proven remarkably resilient, ${ }^{176}$ but upon closer inspection the general principle that false negatives are always to be preferred over false positives is too coarse. Instead, more nuanced criteria should be considered-specifically, the impact and frequency of each type of error. ${ }^{177}$ Everything else equal, if one of the two types of errors results in greater negative impact on welfare, then the test that is more susceptible to this error type should be disfavored. And, again everything else equal, if one of the two error types is more likely to occur, then the test that is more susceptible to this error type should be disfavored.

\begin{tabular}{|l|c|c|}
\hline & Existing tests & Commonness test \\
\hline Negative impact of errors & High & Medium \\
\hline Social cost of errors & Low & Medium \\
\hline Potential of mitigating mechanisms & High & Medium/Low \\
\hline Durability of errors & High & Unknown \\
\hline Frequency of errors & \multicolumn{2}{|c|}{} \\
\hline \multicolumn{2}{|c|}{ Table 1: Comparison of error cost between existing and proposed tests } \\
\hline
\end{tabular}

A confluence of factors determines the severity of negative impact, including the actual social welfare cost, the mitigating effects of any available corrective or second-best mechanisms to limit the harm, and the durability of the error until it dissipates from the market (see Table 1).

The social cost of false positives is generally seen as high. Once a practice is deemed to be anticompetitive, its benefits are lost, not just for the introducing firm, but for any other firm that was considering engaging in the practice. ${ }^{178}$ This is a significant cost, because it negates the benefits of static and dynamic efficiency across the market as far as the banned practice is concerned. But to that we should add the broader and surreptitious cost of hostile signaling to the market—without justifications and

\footnotetext{
${ }^{175}$ Easterbrook, supra note 114; Evans \& Padilla, supra note 22.

${ }^{176}$ Fred S. McChesney, Talking 'Bout My Antitrust Generation: Competition for and in the Field of Competition Law, 52 Emory L.J. 1401 (2003).

${ }^{177}$ Alan Devlin \& Michael Jacobs, Antitrust Error, 52 Wm. \& MARy L. Rev. 75 (2010); Salop, supra note 22 .

${ }^{178}$ Easterbrook, supra note 114; Evans \& Padilla, supra note 22.
} 
efficiencies, the challenged practice may not survive. ${ }^{179}$ This has an additional chilling effect, as the stricter the standard antitrust laws adopt, the greater the deterrent effect regardless of its intensity in absolute terms. ${ }^{180}$ Because of their susceptibility to false positive errors, existing competition on the merits tests result in overdeterrence compared to the commonness test, which increases the social cost.

The commonness test on the other hand, suffers from the opposite weakness-susceptibility to welfare-reducing practices, the cost of which can be high. ${ }^{181}$ However, the social cost of false negative errors of the commonness test is discounted by one important factor. Presumably, anticompetitive practices are not purely harmful-they also generate benefits for the introducing firms. Otherwise, they would not be adopted. As a result, the negative externalities of anticompetitive practices are partly offset by the internalized benefits to the firms that engage in the practice, whereas in the case of false positive errors of existing tests, there is no benefit to anyone, as the benefits of procompetitive practices are lost erga omnes.

In fact, some of the benefits accrued to the firm can then be rolled over to consumers. Examples include additional research and development or savings from economies of scale, either because the offending firm is "benevolent" 182 or as part of the firm's effort to escape potential future enforcement action against it. The point here is not to condone anticompetitive practices, but to say that for every permitted anticompetitive practice, there is some benefit and therefore an overall lower social

\footnotetext{
${ }^{179}$ See Jonathan Baker, The Case for Antitrust Enforcement, 17 J. Econ. Persp. 27 (2003). This follows from the general observation that the way a rule is designed affects the behavior of the subjects of the rule. See Joseph Raz, The Authority of Law (2009).

${ }^{180}$ On the varying degrees of the deterrent effect of antitrust law, see Fiammetta Gordon \& David Squires, The Deterrent Effect of UK Competition Enforcement, 156 De Economist 411-32 (2008); Kai Hüschelrath, Nina Leheyda \& Patrick Beschorner, The Deterrent Effect of Antitrust Sanctions: Evidence from Switzerland, 56 Antitrust Bull. 427 (2011). But see John S. Thompson \& David L. Kaserman, After the Fall: Stock Price Movements and the Deterrent Effect of Antitrust Enforcement, 19 Rev. Indus. Org. 329 (2001).

${ }^{181}$ Salop, countering Easterbrook, is concerned that "when there are high entry barriers, a destroyed entrant likely cannot be resurrected or replaced." Salop, supra note 22, at 350.

${ }^{182}$ See, e.g., Ohio v. Am. Express Co., 138 S. Ct. 2274 (2018), wherein American Express claimed that increased merchant's fees are passed on to consumers in the form of loyalty benefits.
} 
cost compared to banned procompetitive practices that do not benefit anyone.

Moreover, in the case of permitted anticompetitive practices there are mitigating mechanisms to limit the extent of the harm, whereas in the case of banned procompetitive practices, all of their value is lost. This is because they cease to exist altogether, and their benefit is impossible to recover unless firms nevertheless engage in them and thereby risk enforcement action. ${ }^{183}$ Devlin and Jacobs counterargue that second-best practices that carry some of the procompetitive value of the banned practice but none of the anticompetitive elements may partly contain the loss. ${ }^{184}$ While plausible, this argument expresses more of a hope than a reliable solution, as it is unknown how closely second-best practices will match the procompetitive value of the original banned practice. Moreover, because second-best practices could have arisen, even in the presence of the original banned practice, the latter remains as the net loss in both cases. ${ }^{185}$

On the other hand, the impact of common anticompetitive practices of the sort that could be permissible by the commonness test should be mitigated through what is generally considered the most appropriate mechanism-regulation. While antitrust law is appropriate for surgical intervention to rectify isolated anticompetitive conduct, ex ante rulemaking is superior when dealing with issues of potentially broad application or effects. ${ }^{186}$ A number of reasons support that conclusion, including fairness, legal certainty, and the prescriptive nature of rulemaking when the problem is established or foreseeable. ${ }^{187} \mathrm{I}$ am not making a general comment on the superiority of regulation, and in fact I am sympathetic to concerns about the cumbersome aspects of regulation, especially in fast-paced environments. ${ }^{188}$ However, I am using regulation

\footnotetext{
${ }^{183}$ Easterbrook, supra note 114, at 15.

${ }^{184}$ Devlin \& Jacobs, supra note 177.

${ }^{185}$ See Manne \& Wright, supra note 113, at 182.

${ }^{186}$ Richard K. Berg, Re-Examining Policy Procedures: The Choice Between Rulemaking and Adjudication, 38 Admin. L. Rev. 149 (1986); David L. Shapiro, The Choice of Rulemaking or Adjudication in the Development of Administrative Policy, 78 HARv. L. Rev. 921 (1965).

${ }^{187}$ See Warren E. Baker, Policy by Rule or "Ad Hoc" Approach. Which Should It Be?, 22 L. \& CoNTEMP. Probs. 658 (1957).

${ }^{188}$ This concern is older than commonly assumed. See Bernie Burrus \& Harry Teter, Antitrust: Rulemaking v. Adjudication in the FTC, 54 GEo. L.J. 1106 (1966).
} 
in the broadest sense to encompass any method of proscribing conduct, which can range from traditional command and control regulation to light and flexible regulatory methods such as nudging ${ }^{189}$ and "raised eyebrow" regulation. ${ }^{190}$ Therefore, introducing regulation as a complementary mechanism to antitrust enforcement ${ }^{191}$ can be an appropriate response when dealing with repeat offenses without this necessarily involving the traditional woes of heavy-handed regulation. A good example is the expansion of the Federal Communications Commission's (FCC) regulatory powers over interconnection disputes on the Internetpreviously handled as a private or antitrust matter-when the FCC noticed the increasing frequency and severity of the disputes. ${ }^{192}$ Interestingly, the FCC did not exercise its full regulatory arsenal in interconnection disputes, but rather relied only on the "light touch" regulatory backstop of a flexible rule that prohibits common carriers from engaging in "unjust and unreasonable" practices. ${ }^{193}$

The third determinant concerns the durability of errors. Easterbrook submits that the results of the error of banning procompetitive practices are permanent, because the act of banning means that the challenged practice has been given due consideration and has been found illegal. This characterization is bound to persist until and unless the case law is reversed-an uncommon occurrence. ${ }^{194}$ Others rightfully contest the total irreversibility of judicial errors, claiming that courts can and do depart from prior case law. ${ }^{195}$ But it is fair to say that abandoning prior

\footnotetext{
${ }^{189}$ Robert Baldwin, From Regulation to Behaviour Change: Giving Nudge the Third Degree, 77 Modern L. Rev. 831 (2014).

${ }^{190}$ In the words of Clay Whitehead, former President Richard Nixon's Head of the Office of Telecommunications Policy, "[t]he value of the sword of Damocles is that it hangs, not falls." See Kimberly Zarkin \& Michael Zarkin, The Federal Communications Commission: Front Line in the Culture and Regulation Wars (2006) (quoting Whitehead).

${ }^{191}$ Stephen Breyer, Regulation and Its Reform (1982).

${ }^{192}$ FCC, In re: Protecting and Promoting the Open Internet, Report and Order on Remand, Declaratory Ruling, and Order, 29 FCC Rcd. 5561(7), ๆศ 199-202 (Mar. $12,2015)$.

${ }^{193}$ Id. ๆ 203.

${ }^{194}$ Easterbrook, supra note 114, at 15. See also Oona Hathaway, Path Dependence in the Law: The Course and Pattern of Legal Change in a Common Law System, 86 Iowa L. Rev. 601 (2001).

${ }^{195}$ Devlin \& Jacobs, supra note 177; Salop, supra note 22.
} 
case law that deems conduct anticompetitive is arguably harder than starting to prosecute conduct that was thought to be innocuous. In the latter case there is no prior binding practice. Most importantly, even when the commonness test fails to ban an anticompetitive practice because it is found to be common and not designed to harm competition, there is a self-correcting mechanism. As our understanding of a common practice improves, and evidence of its anticompetitive effects increases, it becomes harder for the challenged firm to claim that the practice was not designed to harm competition, which would cause it to fail the commonness test. Therefore, the possibility that the commonness test will allow anticompetitive practices in the long run is low.

The preceding analysis on the gravity of error cost makes a reasonable case for the commonness test in terms of its expected error cost compared to existing competition on the merits tests. The last factor is frequency of errors. Everything else equal, if a test is more likely to result in errors, it should be disfavored compared to other tests. It is common knowledge that existing competition on the merits tests comes with an extensive record of wrongfully banning welfare-enhancing practices (false negatives are far less common), and therefore they exhibit frequent errors. ${ }^{196}$ So widespread has been the suspiciousness of antitrust law against seemingly anticompetitive-though in reality neutral or procompetitive-business practices, that at its height it earned the "inhospitality tradition" stigma. ${ }^{197}$ The number of practices that used to be considered per se illegal but gradually moved toward an effects-based approach is a testament to all the potential false positive errors committed throughout this time. ${ }^{198}$ The preservation of the per se label for some practices (especially in the European Union), despite evidence of potentially procompetitive justifications, suggests further errors.

Since the commonness test has not yet been implemented, there is admittedly little room for meaningful comparison regarding frequency. But at least one available study is reassuring that the application of the

\footnotetext{
${ }^{196}$ See, e.g., Manne \& Wright, supra note 113, at 172-83 (documenting antitrust cases that involved technological innovations).

${ }^{197}$ Easterbrook, supra note 114, at 4 .

${ }^{198}$ William Kovacic \& Carl Shapiro, Antitrust Policy: A Century of Economic and Legal Thinking, 14 J. Econ. Persp. 43 (2000).
} 
commonness test may result in fewer errors. In an ex post study of whether thirteen landmark cases were decided correctly by courts applying current tests, Nalebuff and Majerus found a thirty percent error rate. ${ }^{199}$ Of the wrongly decided cases, three involve facts that suggest that the practices under question were common, including tying household tools to supplies, bundling holiday package services, and bundling phone and broadband service. ${ }^{200}$ This means that, assuming they were not designed to harm competition, an application of the commonness test would have allowed them, as they should have been according to the authors of the study.

In summary, preliminary evidence suggests that incorporating commonness into the heuristic of normal competition will enhance antitrust analysis. In the end, even if the commonness test remains unused, it at least stands as a reminder that antitrust law should factor in how businesses commonly conduct themselves in the market.

\section{Conclusion}

A number of observations and arguments were made in this article. First, the article revealed the absolute dominance of business justifications and efficiencies as proxies to distinguish between normal and anticompetitive practices. Second, it provided the first systematic explanation as to why the universality of business justifications and efficiencies is problematicit detaches antitrust law from the reality of the very subjects it purports to regulate. Third, it introduced commonness of a business practice as a new parameter to identify normal competition. Lastly, it developed an error cost framework to prove that the commonness parameter can enhance the process of identifying which practices should be considered normal competition.

Taken together, these contributions are important for multiple reasons. The obsession of antitrust law with business justifications and efficiencies has remained unobserved and the associated problems underestimated.

\footnotetext{
${ }^{199}$ Barry Nalebuff \& David Majerus, Bundling, Tying, and Portfolio Effects (Part 2), DTI EcoNOMICS PAPER (2003), https://www.immagic.com/eLibrary/ARCHIVES/GENERAL/UK_DTI/ T030207N.pdf.

${ }^{200} I d$. The three cases involve Hilti Aktiengesellshaft, United Kingdom foreign package holidays and insurance, and British Telecom telephone and internet bundling.
} 
Antitrust law has been successful in incorporating lessons from industrial economics, the field that studies how firms interact with each other in the market, but less so from managerial economics, the field that studies how firms behave. This article serves as a reminder that the modus operandi of firms should not be ignored-otherwise, antitrust law risks becoming irrelevant. More substantially though, this article puts forth a specific proposal for how this can be achieved and provides a transparent comparative assessment of the proposal. In effect, this article becomes the first one to challenge the universal adoption of competition on the merits and to propose a workable alternative solution. 